DOSSIÊ

EDUCAÇÃO DE JOVENS E ADULTOS II

arquivos analíticos de políticas educativas

Revista acadêmica, avaliada por pares, independente, de acesso aberto, e multilíngue

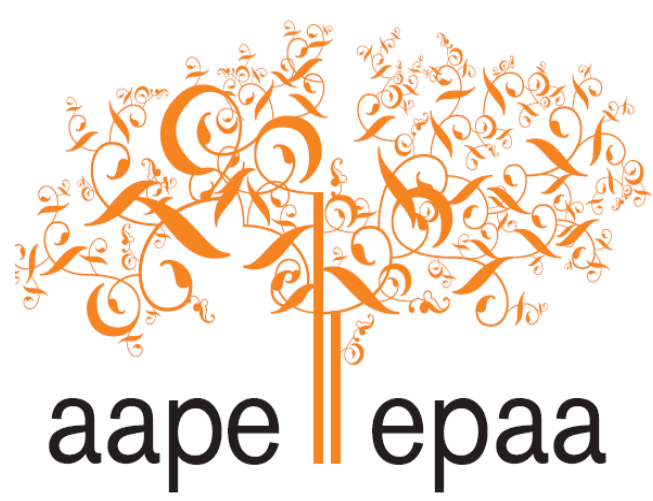

Arizona State University

ISSN 1068-2341

\title{
A permanência escolar na Educação de Jovens e Adultos: proposta de categorização discursiva a partir das pesquisas de 1998 a 2012 no Brasil
}

\author{
Gerson Tavares do Carmo \\ Universidade Estadual do Norte Fluminense Darcy Ribeiro \\ ¿r \\ Cintia Tavares do Carmo \\ Instituto Federal de Educação, Ciência e Tecnologia do Espírito Santo \\ Brasil
}

Citação: Carmo, G. T. \& Carmo, C. T. (2014). A permanência escolar na Educação de Jovens e Adultos: proposta de categorização discursiva a partir das pesquisas de 1998 a 2012 no Brasil. Arquivos Analiticos de Políticas Educativas, 22(63). http://dx.doi.org/10.14507/epaa.v22n63.2014. Dossiê Educação de Jovens e Adultos II. Editoras convidadas: Sandra Regina Sales \& Jane Paiva.

Resumo: O presente trabalho configura-se como um ensaio a respeito da noção de permanência escolar, com foco na Educação de Jovens e Adultos (EJA). Considerando que o termo permanência, a partir de 2007, é mencionado cada vez com maior frequência nos títulos das publicações investigadas, entende-se que a preocupação em melhor definir ou delimitar os aspectos implicados no permanecer na escola anuncia mudanças no modo de refletir sobre a evasão e o fracasso escolar de jovens e adultos. Se o senso comum, de alunos e gestores, atribui ao aluno a responsabilidade pela sua evasão ou fracasso escolar, as crescentes formulações em trono da noção de permanência, embora de forma incipiente, vão apontar para situações, empíricas ou não, nas quais outros operadores educacionais, além do aluno, assumem coletivamente tal responsabilidade. O primeiro objetivo deste 
ensaio é categorizar as formas de abordar o termo permanência escolar, relacionadas direta ou indiretamente com a EJA, presentes em trinta e uma publicações nacionais, no período entre 1998 a 2012. O segundo é apontar que as abordagens dos pesquisadores podem ser consideradas como uma gênese de construção coletiva, mesmo que ainda em formação dispersa, tendo em vista que, como inferimos, escolhem o objeto permanência escolar pelo fato de o tomarem como um lugar de experiência instituinte para agir, refletir e escrever sob o princípio do direito à qualidade da educação no Brasil. A discussão é conduzida por meio da noção de experiência instituinte de escrever sobre a permanência escolar em tensão com um discurso estabelecido sobre a evasão escolar entre jovens e adultos.

Palavras-chave: Educação de Jovens e Adultos; permanência escolar, direito à educação.

\section{The school attendance in Education for Youth and Adults: discursive categorization proposed research from 1998 to 2012 Brazil}

Abstract: The present study was designed as a test in relation to the notion of school attendance, with a focus on Youth and Adult Education (EJA). Considering that the term permanence, from 2007, is mentioned with increasing frequency in the titles of publications investigated, it is understood that the concern to better define or delineate the issues involved with staying in school announces changes in the way we reflect on dropout and failure of school youth and adults. If common sense, from students to managers, gives the student the responsibility for their evasion or school failure, the growing formulations about the notion of permanence, although in an incipient way, will point to situations, empirical or not, in which other educational operators, besides the student, assume collectively such responsibility. The first goal of this article is to categorize ways to approach the term school permanence, directly or indirectly related to the EJA, present in thirty one national publications, in the period from 1998 to 2012. The second is to point that the researchers approaches can be considered as a genesis of collective construction, even if still in dispersed formation, given that, as we infer, choose the object school permanence because they take it as a place of instituting experience to act, reflect and write under the principle of the quality education right. The discussion is conducted through the notion of instituting experience of writing about school permanence in tension with an established discourse about school evasion among youth and adults.

Keywords: Young and Adult Education, PROEJA, school permanence, right to education.

\section{La permanencia escolar en la Educación de Jóvenes y Adultos: propuesta de categorización discursiva a partir de las investigaciones de 1998 a 2012 en Brazil}

Resumen: El presente trabajo se configura como un ensayo en relación a la noción de permanencia escolar, con foco en la Educación de Jóvenes y Adultos.

Considerándose que el término permanencia, a partir de 2007, se menciona cada vez con más frecuencia en los títulos de las publicaciones investigadas, se entiende que la preocupación en definir o delimitar mejor los aspectos implicados en el permanecer en la escuela anuncia cambios en el modo de reflexionar sobre la evasión y el fracaso escolar de jóvenes y adultos. Si el sentido común, de alumnos a gestores, atribuye al alumno la responsabilidad por su evasión o fracaso escolares, las crecientes formulaciones sobre la noción de permanencia, aunque en forma incipiente, apuntan situaciones, empíricas o no, en las que otros operadores educacionales, además del alumno, asumen colectivamente tal responsabilidad. El primer objetivo de este artículo es categorizar las formas de tratar el término permanencia escolar relacionadas directa o indirectamente a la Educación de Jóvenes y Adultos, presentes en treinta y una publicaciones nacionales correspondientes al período entre $1998 \mathrm{y}$ 2012. En segundo lugar se pretende mostrar que los abordajes de los investigadores pueden ser considerados como génesis de construcción colectiva, mismo que todavía de forma dispersa, considerando que, como inferimos, eligen el objeto permanencia escolar por el hecho de tomarlo como 
un lugar de experiencia instituyente para actuar, reflexionar y escribir bajo el principio del derecho a la calidad de la educación. La discusión se conduce por medio de la noción de experiencia instituyente de escribir sobre la permanencia escolar en tensión con un discurso establecido sobre la evasión escolar entre jóvenes y adultos.

Palabras-clave: Educación de Jóvenes y Adultos; permanencia escolar; derecho a la educación

\section{O terreno da pesquisa}

A expressão permanência escolar chamou-nos a atenção pela primeira vez, no final de 2009, quando foi concluída uma revisão bibliográfica de cem publicações acadêmicas a respeito de evasões e retornos escolares na Educação de Jovens e Adultos (EJA) para uma pesquisa de doutoramento. $\mathrm{Na}$ ocasião, foi preciso buscar também publicações sobre a permanência escolar para tecer comentários sobre um gráfico do tempo de permanência dos alunos de EJA em um dado município. No entanto, encontramos apenas três trabalhos que mencionavam o termo permanência no título. Desses três encontrados, em apenas um, a permanência, era tratada como objeto de pesquisa.

A enorme diferença gerou estranheza. Por que o excesso de trabalhos com foco na evasão, se a permanência escolar é o seu correspondente desejado? À época, aventou-se a possibilidade desse "fenômeno" ser fruto de um discurso construído (Orlandi, 2005) e naturalizado em torno da evasão escolar na EJA. Logo, o discurso circulante sobre a evasão não a explica, mas, pelo contrário, a reforça, vinculando recursivamente os baixos resultados da modalidade, principalmente, ao desinteresse dos jovens ou ao cansaço e necessidade do trabalho entre os adultos (Carmo, 2010).

Essa descoberta foi reforçada pelo trabalho de Mileto (2009) $)^{1}$ que discutia com profundidade, estratégias de permanência escolar em turmas de EJA, dos anos finais do Ensino fundamental, em escolas públicas.

Em 2012, após dois anos das primeiras reflexões, voltamos ao tema permanência escolar, a partir de uma nova revisão bibliográfica, ainda com a mesma curiosidade e um estranhamento sobre essa possível tendência de estudo diferenciada sobre as "idas e vindas" de jovens e adultos à escola.

Nessa retomada do tema, perguntamo-nos: por que são encontrados tão poucos estudos exclusivos sobre a permanência escolar, se desde a LDBEN n. 9394 de 1996, em seu Art. $3^{\circ}$ Inciso I, ela está legitimada institucionalmente pelo "princípio da igualdade de condições para o acesso e permanência na escola"? E na direção contrária, por que tantos trabalhos popularizaram a expressão "acesso e permanência na escola" como se fosse uma palavra composta de significado único, sem dar visibilidade especificamente à permanência? E finalmente, por que a visibilidade dessa expressão não interessou a academia por mais de uma década (após 1996) e a da evasão escolar sim, se esta última não consta em qualquer artigo da LDBEN vigente?

Essas foram perguntas problematizadoras que intencionamos apontar e pensar sobre elas de um dado ponto de vista, a partir de uma expressão de Bourdieu (1988), que destaca o "pensamento impensado" para produzir categorias com as quais poderemos delimitar nosso pensar.

Utilizamos a internet como suporte para busca de títulos com o termo permanência em bancos de teses disponibilizados por universidades brasileiras e em revistas científicas disponibilizadas no Google scholar, em língua portuguesa. Deste modo, foram desconsiderados trabalhos ou projetos sobre permanência não produzidos em instituições ou setores de pesquisa, públicos ou privados.

Observamos, também, a existência de pesquisas que abordavam o termo permanência fora do viés da

${ }^{1}$ Mileto, Luiz Fernando. Dissertação defendida em agosto de 2009, na Universidade Federal Fluminense, sob a orientação do Prof. Osmar Fávero, com o título No mesmo barco, dando força, um ajuda o outro a não desistir. estratégias e trajetórias de permanência na Educação de Jovens e Adultos. 
educação, por exemplo: permanência de idosos em asilos e permanência em filas, que foram igualmente desconsiderados.

Antes de iniciar a busca, definimos o recorte temporal. Estabelecemos o intervalo de dezembro de 1996 a outubro de 2012. O limite inicial coincide com o mês da homologação da LDBEN n. 9394/96. O limite final foi o mês em que, arbitrariamente, estabelecemos encerrar a busca devido ao prazo que tínhamos para submissão do ensaio.

Embora Haddad, em 1987 (p. 33), faça alusão à expressão permanência escolar para explicar diferenças de gênero, quando compara pesquisas da década de 1970; e, em 1988, a Constituição Federal (CF) do Brasil, no Artigo 206 2 , Inciso I; preferimos fazer o recorte temporal a partir da LDBEN n. 9394/96 porque será nessa lei que a expressão terá desdobramentos ${ }^{3}$ que ampliam a compreensão e o sentido expressos no Artigo 206 da CF (1988), podendo, portanto, ser objeto de reivindicação de direito constitucional pela sociedade.

Considerado o recorte temporal, o primeiro critério foi reunir pesquisas que tratavam apenas da permanência com viés na educação, independente da área de conhecimento do pesquisador (educação, sociologia, economia etc.) ou do nível de ensino/modalidade de educação (Educação de Jovens e Adultos, Educação Profissional Técnica, Educação a Distância, Ensino Médio Integrado, Ensino Superior etc.). Neste grupo encontramos 44 publicações.

Das 44 publicações encontradas, 70\% delas, num total de 31, abordavam, direta ou indiretamente, sujeitos alunos de EJA. Dessa forma, foi sobre esse corpus de 31 publicações que desenvolvemos nosso trabalho. As outras 13 publicações, em maioria, serviram-nos em duas direções: a) constatar que a preocupação com a permanência escolar abrange todos os níveis de ensino e modalidades de educação cujos sujeitos alunos têm mais de quinze anos; b) reunir diferentes abordagens do tema, ampliando e aprofundando assim a discussão sobre permanência escolar de alunos oriundos das camadas populares.

Desse total de publicações, três são teses, 14 são dissertações e 14 são artigos acadêmicos. Dentre elas, 26 (84\%) têm a palavra permanência no título, e cinco apresentam termos similares como: trajetória ininterrupta, longevidade escolar, entre outras. Considerando que a mais antiga publicação encontrada é de 1998, e as mais recentes de 2012, as 31 publicações ${ }^{4}$, estão distribuídas num período de 15 anos, apesar de o nosso critério de corte remontar a 1996 - ano da homologação da LDBEN n. 9394.

Nessa nova investida de revisão de literatura sobre permanência escolar, foi com curiosidade que observamos um crescente interesse pela temática com o passar dos anos. Para efeito de comparação e de contextualização histórica estabelecemos recortes temporais coincidentes com os períodos de governo desde 1996, considerando ser o Estado o principal indutor de políticas públicas defini، lei, e que cada governo possui características próprias, diferenciando-se quanto a prioridades de investimento na EJA.

\footnotetext{
${ }^{2}$ Art. 206 - O ensino será ministrado com base nos seguintes princípios: I - igualdade de condições para o acesso e permanência na escola.

${ }^{3} \mathrm{Na}$ LDBEN n. 9394/96, a expressão aparece em quatro de seus oito Títulos: II - Art. $3^{\circ}$ Inciso I; III Art. 4 Inciso IV; IV - Art. 14; e V - Art. 37 parágrafo segundo. Este último, referindo-se à Educação de Jovens e Adultos como modalidade, explicita: "\$ $2^{\circ} \mathrm{O}$ poder público viabilizará e estimulará o acesso e a permanência do trabalhador na escola, mediante ações integradas e complementares entre si".

${ }^{4}$ As 31 publicações selecionadas estão listadas no Apêndice 1 e classificadas no Apêndice 2. O primeiro autor de cada publicação tem um código que permite identificar a publicação no Apêndice 2 e também no tópico das referências bibliográficas, no qual estão citadas todas as publicações selecionadas mesmo que não tenham sido citadas no corpo do texto. Esse procedimento foi adotado para que o leitor interessado possa acessar qualquer uma delas.
} 
Assim, no período de 1996 a 2002 que abrange o $1^{\circ}$ e $2^{\circ}$ governos do presidente Fernando Henrique Cardoso, encontramos apenas uma tese (doutorado) em 1998. No período de 2003 a 2006, do $1^{\circ}$ governo do presidente Luiz Inácio Lula da Silva, encontramos cinco publicações. No $2^{\circ}$ governo do presidente Lula, de 2007 a 2010, já verificamos um salto para 15 publicações, e no governo seguinte, nos dois primeiros anos da presidenta Dilma Roussef, encontramos dez publicações.

No quadro a seguir podemos observar a evolução da produção das publicações, conforme os períodos de governo:

Quadro1.

Distribuição absoluta e percentual das publicações sobre "permanência" escolar por períodos de governo federal do Brasil.

\begin{tabular}{|c|c|c|c|c|}
\hline $\begin{array}{c}1996-1998 \\
1^{\circ} \text { governo FHC }\end{array}$ & $\begin{array}{c}1999-2002 \\
2^{\circ} \text { governo FHC }\end{array}$ & $\begin{array}{c}2003-2006 \\
1^{\circ} \text { governo Lula }\end{array}$ & $\begin{array}{c}2007-2010 \\
2^{\circ} \text { governo Lula }\end{array}$ & $\begin{array}{c}2011-2012 \ldots \\
\text { governo Dilma }\end{array}$ \\
\hline 1 & 0 & 4 & 15 & 11 \\
\hline $3 \%$ & $0 \%$ & $13 \%$ & $48 \%$ & $36 \%$ \\
\hline
\end{tabular}

Legenda: FHC - Presidente Fernando Henrique; Lula - Presidente Luiz Inácio Lula da Silva; Dilma -

Presidenta Dilma Roussef (metade do período de governo)

Fonte: Elaboração dos autores.

Se reunirmos os percentuais expressos no Quadro $1 \mathrm{em}$ dois grupos, tendo como referência de corte o ano 2007, teremos o primeiro grupo com 16\% (período de 1996 a 2006) e o segundo com 84\% (período de 2007 a 2012), cuja diferença é mais do quíntuplo (525\%) de publicações entre um período e outro 5 .

O primeiro aspecto que destacamos para os objetivos desse trabalho é a diferença de quantidade de publicações nos dois períodos citados, ao longo de quinze anos (considerando que a pesquisa mais antiga é de 1998).

Embora não seja nosso propósito investigar as causas dessa evolução numérica, podemos apontar alguns fatores como "pistas" "prováveis para a sua ocorrência, de modo que essas possam contribuir no processo de construção da argumentação desse trabalho:

a- $\mathrm{O}$ reduzido investimento em EJA nos governos FHC - um exemplo desse descaso pode ser verificado no trecho a seguir, extraído da tese de Paiva (2005, p. 110) "o texto Diretrizes para a educação de jovens e adultos em 1996 [...] trata de afirmar o pensamento e a forma de conduzir a área de EJA por meio das políticas públicas. Por ele observam-se as discrepantes concepções metodológicas do governo brasileiro e a perspectiva apontada pela Unesco/OREALC na condução das atividades preparatórias e para a própria Conferência. Embora afirmando a área como uma das prioridades do Governo Fernando Henrique Cardoso, a leitura do texto, no entanto, vai trazendo à luz o verdadeiro lugar reservado à EJA, assim como a concepção restrita - a de escolarização de quem não teve sucesso na escola - com a qual os dirigentes da SEF se pautavam para responder às 'demandas de uma parcela da população que não foi

\footnotetext{
${ }^{5}$ Este ensaio analisou o universo das 31 publicações encontradas. Entretanto, mesmo apoiados na certeza de que há mais publicações sobre a permanência escolar no intervalo delimitado, os autores lançam a hipótese (para futuros trabalhos) de que a proporcionalidade temporal encontrada tenderá a ser mantida.

${ }^{6}$ Aqui tomamos o termo "pistas" no sentido dado por Ginzburg (2002) sob a perspectiva do "paradigma indiciário".
} 
atendida na época devida por interposição de determinantes internos e externos ao sistema educacional". (BRASIL, 1996, p. 1);

b- Os efeitos do aumento das discussões sobre a EJA no país, em função do elevado número de criação de Fóruns de EJA nos 26 Estados, a partir de 2003, quando tem início o primeiro governo Lula - para ilustrar esta "pista", reproduzimos o resumo do trabalho de Dantas (2009, p. 1) sobre as influências dos Fóruns de EJA nas políticas educacionais do governo Lula: "A educação de jovens e adultos, ao longo da história do país, evidencia o insuficiente empenho do Estado na promoção de políticas que garantissem o direito de todos à educação. A luta atual pela EJA vai além da dívida social a ser reparada pelo Estado, mas acontece, principalmente, para afirmá-la como um direito. $\mathrm{Na}$ atualidade, esta luta tem como expressão os Fóruns de EJA. Estes se constituem como uma articulação de diversos atores que se propõe discutir temas como: alfabetização, formação de professores, qualificação profissional de jovens e adultos etc. Esta mobilização luta por políticas públicas para a EJA que efetivem o direito à educação independente da idade enunciado na Constituição. A presente pesquisa pretende compreender como os Fóruns têm se mobilizado na luta pelo direito à educação e por políticas públicas para jovens e adultos. Supõe-se que esses novos sujeitos coletivos passaram a pautar, modificar e interferir nas agendas políticas, promovendo embates que têm, no diálogo, forte identificação. O estudo tem seu destaque pelo reconhecimento dos Fóruns como interlocutores legítimos das instâncias ministeriais. Os dados parciais da investigação apontam a existência de 26 fóruns estaduais e um no Distrito Federal, além de 52 fóruns regionais que estão desempenhando papel expressivo na atualidade, na articulação com o poder público na formulação de políticas públicas de direito para a área";

c- A quase universalização do acesso à escola, que possibilitou redirecionar esforços da luta pela quantidade de vagas para a qualidade da educação em sala de aula, de forma a "completar" o binômio acesso e permanência preconizado na Constituição e na LDBEN vigentes - nesse caso, seguimos a seguinte afirmação de Oliveira e Araújo (2005, p. 9) quanto aos efeitos do processo de universalização do acesso à escola: "[...] a ampliação das oportunidades de escolarização da população gerou obstáculos relativos ao prosseguimento dos estudos desses novos usuários da escola pública, visto que não tinham as mesmas experiências culturais dos grupos que tinham acesso à escola anteriormente, e esta não se reestruturou para receber essa nova população. Dessa forma, os obstáculos à democratização do ensino foram transferindo-se do acesso para a permanência com sucesso no interior do sistema escolar".

d- A saturação dos modelos teóricos e metodológicos das pesquisas que investigam a evasão escolar, cujos resultados apontam como motivo da evasão a necessidade de trabalhar, ou o desinteresse pelos estudos. Esses critérios indicam responsabilização individual dos sujeitos alunos por deixarem a escola; ${ }^{7}$

e- A iniciativa, ainda de forma isolada, de pesquisadores ou instituições que, para sair do círculo vicioso das explicações "saturadas" sobre a evasão, apostam na permanência como uma "luz no fim do túnel" de forma a reorientar seus aparatos teóricometodológicos.

\footnotetext{
${ }^{7}$ As "pistas" de e não estão comentadas porque são complementares, conformando o objeto de nosso ensaio.
} 
Essas "pistas", além de apontarem para possíveis causas de aumento de publicações sobre a permanência escolar, contribuíram na condução das ideias e dos argumentos na construção do que entendemos ser o que define esse trabalho: uma revisão bibliográfica com características de ensaio, devido ao pequeno número de publicações analisadas. Portanto, o segundo aspecto que destacamos para o interesse dos objetivos desse ensaio é a tímida produção acadêmica sobre o tema. Ao compararmos o total de produção sobre permanência escolar com a produção em torno do tema evasão ou fracasso escolar nesse período, o número ultrapassa 1.000 (mil) publicações só no período de 1996 a 2007, conforme apresenta Bragança (2008, p. 21). Dessa forma, pode-se constatar que a diferença é abissal. Contudo, a "pista $e$ " mencionada anteriormente, pode ser uma possível causa dessa diferença. Tais iniciativas isoladas de pesquisadores ou instituições que apostam na "permanência" podem ser constatadas quando se observa a dispersão territorial das 20 instituições em que ocorrem pesquisas sobre permanência escolar (ver Apêndice 2).

Acrescentamos que, apesar de concentradas nas Regiões Sul (15 publicações) e Sudeste (13 publicações) - com destaque territorial para o Rio Grande do Sul (8 publicações) e relativo destaque institucional para a UENF, UFMG e UFRGS com 3 publicações cada -, as pesquisas não dialogam entre si, isto é, não se citam mutuamente.

Quanto à área de conhecimento das publicações selecionadas, todas se referem à área da educação. Das 31 publicações, 29 são de programas de educação e têm origem em um programa de sociologia política (ver Apêndice 2).

Apenas uma delas (Noro, 2011) cita seis referências bibliográficas com o termo permanência no título. Entendemos que a pesquisa de Noro (2011) consegue tal feito por que referencia seu trabalho em publicações do Rio Grande do Sul, estado com maior número de instituições pesquisadoras sobre permanência, incluindo três universidades e um CEFET (atual IFSUL - Instituto Federal Sul-RioGrandense). Entre as outras pesquisas que citam trabalhos com o termo permanência no título, duas publicações citam três referências bibliográficas; e quatro citam apenas uma referência bibliográfica com esse tema. Em todas as demais publicações não há títulos, na bibliografia, contendo o termo permanência.

Enfim, para a consecução dos objetivos desse trabalho e para orientar a busca de um caminho metodológico que permitisse promover um diálogo entre tais publicações, partimos dos dois aspectos supracitados, em si contraditórios quantitativamente: $1^{\circ}$ - o aumento de $525 \%$ do número de publicações a partir de 2007, em relação aos períodos anteriores; e $2^{\circ}$ a tímida produção acadêmica de 31 publicações sobre o tema, a partir da publicação da LDBEN n. 9394, em 1996.

Embora cientes de que a crescente - mas ainda incipiente - produção acadêmica nos impeça de apontar qualquer tendência teórico-metodológica nas pesquisas sobre a noção de permanência escolar na EJA, nos permitiremos pensar, dialogar e indagar sobre o tema nas publiçações encontradas.

\section{Objetivos, Pontos de Vista e Horizontes}

O primeiro objetivo deste ensaio é categorizar as formas de abordar o termo permanência escolar relacionada direta ou indiretamente com a EJA, presentes em 31 publicações, no período entre 1998 e 2012.

O segundo objetivo é apontar que as abordagens dos pesquisadores podem ser consideradas como gênese de construção coletiva, mesmo que ainda em formação dispersa. Isso, porque inferimos que estes escolhem o objeto permanência escolar porque o tomam como um lugar de experiência instituinte para agir, refletir e escrever sobre o princípio do direito à qualidade da educação. 
Nesta seção desenvolveremos o que se entende por permanência escolar e por experiência instituinte, bem como justificaremos o ponto de vista dos autores das 31 publicações quando escolhem o objeto permanência escolar e o descrevem intuitivamente como experiência instituinte.

\section{Permanência escolar}

Conforme o Novíssimo Dicionário Latino-Português (Saraiva, 2006) a etimologia de permanecer e permanência tem como referente latino o termo permanere que significa ficar até o fim, persistir, perseverar, durar. O prefixo per- significa por completo (como em perplexo e perseverança) e o verbo manere significa ficar, continuar.

Entretanto, será a partir dos sufixos -ecer e -ência na língua portuguesa que iremos iniciar nossa discussão como exercício da paciência do conceito $^{8}$, conforme apresentado por Gallo (2009) com base na obra do filósofo Gilles Deleuze.

O sufixo - ecer significa processo durativo de determinada extensão de tempo, indica começo de ação ou entrada num estado, como ocorre nos verbos amanhecer, entristecer, crescer, adolescer, envelhecer.

Nesse sentido, a etimologia de permanência (estado, qualidade de permanecer), como palavra derivada, não deveria trazer novidades porque o sufixo -ência teria apenas o papel de substantivar o verbo permanecer. Porém, Lacotiz (2006, p. 322) afirma que "o sufixo possui significado e não apenas transporta a palavra de uma classe a outra", informando aspectos que contribuem para sua polissemia.

Lacotiz (2006, p. 329), ao analisar o sufixo - ançal -ençal -âncial -ência na obra do simbolista João da Cruz e Souza informa que "ao contrário do que é afirmado nas gramáticas, os sufixos em português -ança/ -ença/ -ância/ -ência possuem outros significados que não apenas "estado" ou "ação ou resultado dela", destacando que a análise desses sufixos, na obra de Cruz e Souza, "permitiu-nos captar outros sentidos".

A autora afirma, ainda, que dos sufixos analisados -ência é o mais recorrente e o que possui maior número de significados na obra de Cruz e Souza. De um total de 56 palavras com esse sufixo: "ato durativo de x" aparece em 39,28\% (como em adolescência, efervescência); "propriedade (ou característica) de x" 37,5\% (como em paciência, docência); "resultado de x" $8,92 \%$ (como em advertência, abstinência). O restante distribui-se por mais quatro significados: "excesso de x" 3,57\% (como em corpulência, violência); "faculdade de x" 1,78\% (como em eloquência, eficiência); “disposição de x" 1,78\% (como em benevolência, conivência); e "assemelha-se a x" 5,35\% (como em sonolência, coincidência).

Lacotiz ainda destaca que a obra é da segunda metade do século XIX e que as recorrências dos significados sufixais com maior percentual - "ato durativo de x"; "propriedade (ou característica) de x"; e "resultado de x" - estão presentes ainda nos dias atuais.

Acrescentando mais informações na direção polissêmica do sufixo -ência, a partir de Azevedo (2010, p. 17), o vocábulo permanência encontra-se classificado na categoria MUDANÇA

\footnotetext{
${ }^{8} \mathrm{O}$ trabalho de criação ou de recriação de um conceito exige paciência porque "conceito é a instituição de um acontecimento", suscitado por "problemas vividos na pele, sentidos com intensidade" (Gallo, 2009, p. 181). Como não se consegue resolver os problemas de uma só vez, a paciência é exigida na visita aos conceitos já criados, para recriar ou criar o novo. Para Gallo (2009, p. 282), assim como os problemas devem ser aqueles sentidos com intensidade, os conceitos devem ser "como afetos, que nos tocam ou não, como uma música". É o afeto que possibilita ou não a nossa adesão à perspectiva de paciência do conceito - seja no processo de recriação ou criação conceitual. Para o uso desse ensaio apoiamo-nos na definição de conceito explicitada por Deleuze e Guattari (apud Gallo, 2003, p. 27): “um operador, algo que faz acontecer, que produz". Dessa forma o conceito não é uma opinião, mais apropriadamente é "uma forma de reagir à opinião generalizada".
} 
(Divisão VII), junto com outros sete termos: mudança, cessação, continuação, conversão, reversão, revolução, substituição e troca.

Ao encontrar o verbete permanência em Azevedo (2010, p. 53), percebemos que ele está antecedido pela expressão entre parênteses (Ausência de mudança) e seguido de 39 ideias afins. Conseguimos organizar 36 delas, segundo os três significados mais frequentes para o sufixo -ência encontrados por Lacotiz, dispondo-as em ordem alfabética no quadro a seguir:

Quadro 2.

Ideias afins com o verbete "permanência", considerando a polissemia do sufixo "-ência", encontrada por Lacotiz, na obra de João da Cruz e Souza.

\begin{tabular}{|c|c|c|}
\hline "ato durativo de x" & $\begin{array}{l}\text { "propriedade } \\
\text { (ou característica) de x" }\end{array}$ & “resultado de x" \\
\hline $\begin{array}{l}\text { conservação, constância, desafio } \\
\text { à ação do tempo, insistência, } \\
\text { manutenção, manutência, } \\
\text { persistência, resistência, } \\
\text { sobrevivência, supervivência, } \\
\text { subsistência, preservação. }\end{array}$ & $\begin{array}{l}\text { calma, calmaria, estabilidade, } \\
\text { estagnação, imobilismo, } \\
\text { inalterabilidade, inércia, } \\
\text { marasmo, mesmice, monotonia, } \\
\text { quietude, repouso, rotina, } \\
\text { tautometria, tranquilidade. }\end{array}$ & $\begin{array}{l}\text { imanência, status quo, } \\
\text { intangibilidade, conservantismo, } \\
\text { tradicionalismo, firmeza, } \\
\text { efetividade, uti possidetis } \\
\text { (usucapião), obstinação. }\end{array}$ \\
\hline
\end{tabular}

Fonte: Elaboração dos autores.

Admitindo-se que seja possível lançar dúvida sobre o lugar mais apropriado para cada uma das ideias afins com permanência no quadro acima, o mesmo não é possível admitir em relação ao sufixo ência, no vocábulo permanência. Seguindo o raciocínio de Lacotiz, é possível constatar que o vocábulo também apresenta polissemia suficiente para contrariar a regra de que um sufixo "apenas transporta a palavra de uma classe a outra".

Dessa polissemia destacam-se os significados que, por um lado, atendem à situação de "ausência de mudança" — inércia, imobilismo, mesmice, quietude, monotonia; e, por outro lado, os significados que contradizem essa situação, porque estão associados à noção de duração e, portanto, sujeitos à transformação pela ação do tempo.

Se pensarmos em diferentes instituições em que um indivíduo pode permanecer - escola, hospital, asilo - veremos que cada instituição se adéqua melhor a alguns significados do que a outros. Por exemplo, atribuir à permanência escolar na EJA os significados de resistência, insistência ou sobrevivência é muito mais adequado e coerente com a realidade que vivem jovens e adultos na instituição escola, do que os demais significados constantes do Quadro 2. Isto porque, como afirma Santos (2007, p. 42) a permanência não é "apenas a presença física do aluno em sala de aula" e nem a sala de aula é "um lugar de silêncio", conforme Martins (2006, p. 18).

A pesquisadora Dyane Reis (2009a), em tese doutoral, explora esse contraste presente na polissemia da palavra permanência, quando o significado do sufixo -ência refere-se a "ato durativo de x".

Numa primeira abordagem, a pesquisadora cita a descrição de permanência dada pelo filósofo David Lewis (1986 apud Reis, 2009a, p. 67): "uma coisa persiste se e somente se, existe ao longo do tempo, assumindo partes temporais diferentes ou estágios em tempos diferentes, ainda que nenhuma dessas partes esteja completamente presente em mais do que um momento temporal". A partir daí, Reis (2009a, p. 68) diz que "a persistência corresponde ao modo como algo dura no tempo" e observa que "se delineia aqui uma associação entre permanência e persistência por um lado, e uma relação direta entre permanência e tempo, por outro". 
A segunda abordagem de Reis se apropria da concepção filosófica de permanência em Kant, na obra A Crítica da Razão Pura. Conforme a autora, Kant (apud Reis 2009a, p. 68) ao tratar da permanência também a descreve como processo de duração: "A mudança que se opera não se refere ao tempo em si, mas só aos fenômenos do tempo [...] a mudança é, pois, um modo de existir que resulta, num outro modo de existir, do mesmo objeto".

Reis (2009a, p. 68), após desenvolver seus argumentos nas duas abordagens, as sintetiza articulando-as com elementos da noção de transformação, remetendo-a às trocas humanas portanto simbólicas — de experiências por meio do diálogo:

De um modo geral, pode-se dizer que a permanência é, pois, duração e transformação; é o ato de durar no tempo, mas sob um outro modo de existência. A permanência traz, portanto, uma concepção de tempo que é cronológica (horas, dias, semestres, anos) e outra que é a de um espaço simbólico que permite o diálogo, a troca de experiências e a transformação de todos e de cada um. [...] Assim sendo, permanência é o ato de durar no tempo que deve possibilitar não só a constância do indivíduo, como também a possibilidade de transformação e existência. A permanência deve ter o caráter de existir em constante fazer e, portanto, ser sempre transformação. Permanecer é estar e ser continuum no fluxo do tempo, (trans)formando pelo diálogo e pelas trocas necessárias e construidoras.

Conduzindo seu raciocínio para a realidade de seu objeto de pesquisa - a permanência de negros na universidade - Reis (2009b, p. 4) toma o conceito enquanto continuum através dos tempos que determina a perpetuação do fenômeno, e propõe uma definição de permanência como: [...] o ato de continuar que permita não só a constância do indivíduo, mas também a possibilidade de existência com seus pares. Permanecer não pode ser entendido aqui, como o simples ato de persistir apesar e sob todas as adversidades, mas a possibilidade de continuar estando dentro; estando junto; estando "in". Já que segundo Kant, só pelo permanente recebe a existência, nas diferentes partes da série sucessiva do tempo, uma quantidade que se denomina duração. E esta duração implica em um reconhecimento também pelo outro.

A partir dessa associação entre permanência e reconhecimento social, a pesquisadora propõe uma primazia da relação de coexistência dos pares sobre a existência individual, denominadas permanência simbólica e permanência material, respectivamente:

Ser reconhecido, ser visto pelo outro é a condição da existência simbólica: "eu só existo se o outro me reconhece". E se o outro me reconhece como legítimo, aumentam as minhas chances de fazer parte, de estar junto. [...] Assim sendo, o nosso conceito de permanência possui uma relação direta com a coexistência dos indivíduos em primeiro lugar e sua existência em segundo. Vamos aqui então, chamar a coexistência de permanência simbólica e a existência de permanência material. (Reis, 2009b, p. 5).

Reis (2009b) entende, portanto, permanência simbólica como condições que permeiam possibilidades "que os indivíduos têm de identificar-se com o grupo, ser reconhecido e de pertencer a ele"; e permanência material como condições de subsistência, isto é, recursos materiais e financeiros necessários à existência individual como estudante.

Como é possível observar, mesmo não tratando de permanência no campo da Educação de Jovens e Adultos, mas sim da permanência de estudantes negros no Ensino Superior, Reis (2009b) em seu trabalho lança pistas conceituais para a discussão acadêmica do termo. Tomamos tais pistas sob a perspectiva de uma construção coletiva no exercício da paciência do conceito de permanência escolar. $\mathrm{O}$ exercício visou à expansão de buscas teórico-metodológicas, não só para além das macropolíticas 
aligeiradas que avidamente intentam aumentos dos índices de fluxo escolar, mas, principalmente, as que possam estar mais próximas dos operadores da educação, na construção de micropolíticas comprometidas e perseverantes no caminho da qualidade de ensino para populações desfavorecidas economicamente.

\section{Experiência Instituinte}

Aqui nos apropriamos da categoria experiência instituinte desenvolvida por Linhares (2007) junto à equipe do Centro de Referência e Documentação em Experiências Instituintes (CRDEI/UFF). Suas pesquisas sobre Experiências Instituintes em Escolas Públicas, congrega toda uma bibliografia referente às reformas educacionais, inovações e movimentos instituintes na escola. Além dessas, agrega instrumentos epistemológicos para perceber outros tipos de relações pedagógicas, ainda embrionárias, que prometem alargar práticas e concepções de conhecimento escolar por meio dos quais objeto e sujeito se interpenetram e se conjugam com a vida, assumindo a responsabilidade de exercitá-la de forma respeitosa e includente, representativa de uma educação de qualidade.

Escrever sobre uma experiência instituinte não se confunde com o escrever sobre o novo, ou uma novidade, mas sobre o desafio e tensões vividos pelo próprio pesquisador em sala de aula, em busca de compreender a origem da permanência escolar. O ponto de vista de um pesquisador que escreve sobre a experiência de outro, é radicalmente distinto do ponto de vista do pesquisador que escreve a partir de um espaço próprio que constitui a sua experiência, isto porque se torna sujeito de uma metaexperiência - escrever sobre a própria experiência - passando a ter poder sobre a sua exterioridade. Nesse sentido Bragança (2003) contribui para a distinção dos sentidos de "novo" e "origem" a partir de contribuição de Walter Benjamin:

A experiência instituinte se afirma como uma experiência comum, partilhada por um grupo, contrapondo-se desta forma à experiência pontual e fragmentada do sujeito isolado de seus pares. É uma experiência aberta, que não se afirma como "símbolo", com um significado unilateral, mas como "alegoria" por seus múltiplos sentidos e leituras. Podemos ainda articular este conceito ao sentido de "origem" em Benjamin, pois o instituinte, na perspectiva de nossa pesquisa, não se confunde com o "novo", mas é uma busca constante do movimento emancipador, movimento este que articula passado, presente e futuro.

Contrapondo-se ao modismo e a uma reprodução estática do passado, a experiência instituinte sinaliza a densidade da experiência humana ao rememorar, recuperando, assim, o sentido de uma memória que é capaz de prometer. (Bragança, 2003, p. 1).

Mas este é apenas um aspecto da questão. $\mathrm{O}$ aspecto mais relevante está no fato de que escrever sobre a permanência escolar sob a perspectiva instituinte implica reescrever uma realidade — a da evasão escolar - que está escrita (descrita, narrada, exemplificada e explicada, em suas causas e efeitos) sob uma lógica que tem a naturalização da desigualdade social brasileira como núcleo central de seus argumentos. Nesse sentido, Dominick (2013) aponta, a partir de Castoriadis, para a dinâmica de conexões e litígios entre o instituído e o instituinte:

A permanente conexão entre o instituído e o instituinte ou, como afirma Castoriadis, entre o sincrônico e o diacrônico, são a representação fundamental na construção por ela desenvolvida, pois as experiências instituintes não se encontram em uma redoma, apartadas do instituído. Ambos estão em permanente conexão e em litígio como experiências que se desdobram em movimentos criadores, estremecendo o que foi organizado pela história, que é passível de incorporar o que está em movimento e busca se expandir, adentrando o espaço do outro. (Dominick, 2013, p. 6). 
A partir de Souza (2004), que consultou o Índice do Vocabulário do Português Medieval da Fundação Casa de Rui Barbosa, o verbo "instituir" no século XIV, quando no transitivo direto ou bitransitivo, tinha o sentido diacrônico, antigo, de "dar formação", "educar", "instruir". Já no sentido atual, considerando apenas o transitivo direto, passa a ser compreendido como "dar começo a"; "estabelecer", "criar". Ou ainda, como transitivo direto predicativo e pronominal, significando: "atribuir (a outrem ou a si próprio) uma missão, tarefa"; "nomear-se"; "constituir-se".

Entretanto, essas duas compreensões de "instituir", apesar de distantes no tempo, não são estranhas entre si: "dar começo a", criar, pode ser associado a "dar formação", educar instruir, desde que o estranhamento esteja posto em relação ao instituído.

Quanto ao termo experiência, Bragança (2003) afirma que as reflexões sobre a categoria experiência instituinte "nos leva ao encontro das contribuições de Walter Benjamin [...]. Contribuições que apontam para o sentido das 'experiências plenas', que se traduzem por uma tessitura coletiva e pela possibilidade de abertura polifônica" .

Entretanto, conforme aponta Nascimento (2010, p. 206), o conceito de "experiência plena" (Erfahrung) a que Benjamin ${ }^{10}$ se refere é elaborado a partir da crise da experiência causada pela mudança dos modos de produção artesanal para a produção industrial. Segundo Nascimento (2010, p. 206), para Benjamin:

A articulação entre os meios de produção à experiência parte do fato de que a vida do homem seguia de acordo com o ritmo dos modos de produção medieval. Ou seja, a produção artesanal, lenta, tranquila, que abrangia a totalidade do objeto fabricado, ditava o ritmo da própria vida dos artesãos. Esse ritmo permitia preservar a tradição oral, a construção de uma experiência plena. Porém, com a industrialização, esse ritmo artesanal desapareceu nas grandes cidades. Essa é uma interpretação estratégica sob o ponto de vista de sua teoria da experiência e seu declínio como Erfahrung.

Tal possibilidade, conforme informa Nascimento (2010, p. 212), advém da interpretação que Benjamin faz do poeta Charles Baudelaire, como estratégia fundamental em sua pesquisa sobre o séc. XIX, "pois assegura a importância e consequência das mudanças sociais ocorridas naquele século, das quais decorre também a mudança da percepção humana".

Por isso, entendemos que a noção de "experiência plena" de Benjamin não pode ser "transportada" no tempo, da era pré-industrial para a era do conhecimento, como se fosse possível revivê-la de algum modo. Seria necessário promover um deslocamento conceitual da noção de “experiência plena” para o século atual. Entendemos que esta tarefa é realizada por Larrosa (2002) ${ }^{11}$.

Estamos, portanto, de acordo com Larrosa (2002, p. 2) quando, também a partir de Benjamin $^{12}$, atualiza a discussão sobre "experiência plena" no século XXI, convicto de que as

\footnotetext{
${ }^{9}$ A autora se refere à seguinte obra de Benjamin: BENJAMIN, Walter. Magia e técnica, arte e política. Ensaios sobre literatura e história da cultura. In: BENJAMIN, Walter. (1994). Obras escolbidas. 7. ed., São Paulo: Brasiliense, vol. I.

${ }^{10} \mathrm{O}$ autor se refere à seguinte obra de Benjamin: BENJAMIN, Walter. (1975) Sobre alguns temas em Baudelaire. Trad. Edson A. Cabral, José B. de O. Damião. São Paulo: Abril Cultural, p. 35. Col. Os Pensadores.

${ }^{11}$ Larrosa Bondia, Jorge. Professor titular de teoria e história na Universidade de Barcelona, Espanha

${ }^{12}$ Um exemplo de atualização da noção de experiência de Benjamin em Larrosa pode ser observado na seguinte citação: "A experiência é o que nos passa, o que nos acontece, o que nos toca. Não o que se passa, não o que acontece, ou o que toca. A cada dia se passam muitas coisas, porém, ao mesmo tempo, quase nada nos acontece. Walter Benjamin, em um texto célebre, já observava a pobreza de experiências que caracteriza o nosso mundo, "Nunca se passaram tantas coisas, mas a experiência é cada vez mais rara". (Larrosa, 2002, p. 2).
} 
palavras produzem sentido, criam realidades e, às vezes, funcionam como potentes mecanismos de subjetivação.

O homem é um vivente com palavra. E isto não significa que o homem tenha a palavra ou a linguagem como uma coisa, ou uma faculdade, ou uma ferramenta, mas que o homem é palavra, que o homem é enquanto palavra, que todo humano tem a ver com a palavra, se dá em palavra, está tecido de palavras, que o modo de viver próprio desse vivente, que é o homem, se dá na palavra e como palavra.

Portanto, pela palavra escrita - a mesma que produz a informação que passa e acontece nas notícias, nas telenovelas, nas aulas, nos seminários —, de acordo com Linhares e equipe (2007), é possível viver a experiência que nos passa e nos acontece na academia quando se trata de escrever sobre uma experiência instituinte.

Quanto à noção de experiência, entendemos que Larrosa traz elementos que podem contribuir para sua dimensão polifônica apontada por Bragança (2003). Dissecando a etimologia da palavra experiência, Larrosa (2002, p. 6) escreve:

A palavra experiência vem do latim experiri, provar [experimentar]. A experiência é em primeiro lugar um encontro ou uma relação com algo que se experimenta, que se prova. O radical é periri, que se encontra também em periculum, perigo. A raiz indo-europeia é per, com a qual se relaciona antes de tudo a ideia de travessia, e secundariamente a ideia de prova. Em grego há numerosos derivados desta raiz que marcam a travessia, o percorrido, a passagem: peirô, atravessar; pera, mais além; perâ̂, passar através, perainô, ir até o fim; peras, limite. Em nossas línguas há uma bela palavra que tem esse per grego de travessia: a palavra peiratês, pirata. O sujeito da experiência tem algo desse ser fascinante que se expõe atravessando um espaço indeterminado e perigoso, pondo-se nele à prova e buscando nele sua oportunidade, sua ocasião. Tanto nas línguas germânicas como nas latinas, a palavra experiência contém inseparavelmente a dimensão de travessia e perigo.

Como é possível observar, Larrosa traz elementos mais próximos a nosso objetivo de compreender o ato de um pesquisador escrever sobre permanência escolar como uma experiência instituinte, prescindindo, nesse caso, de fazer referência à noção de "experiência plena" de Benjamin.

Entendemos que são dois esses elementos: a) o primeiro pelo sentido de perigo, porque não há qualquer trabalho dedicado exclusivamente a discutir e a conceituar a permanência escolar ao qual possamos nos remeter, fora da sua dimensão quantitativa, que se confunde com fluxo escolar; b) o segundo pelo sentido de travessia, porque todos os pesquisadores das publicações selecionadas tratam de trabalhos empíricos. Ou seja, configuram seus trabalhos a partir da intenção do percurso de alguma experiência que resultou em uma reflexão acadêmica sobre a permanência.

Acrescentamos que as perspectivas de travessia e perigo de uma experiência instituinte, no século XXI, implicam não só vivê-la, mas também escrevê-la, pois conforme Olson (1997, p. 298), “[...] a nossa concepção moderna do mundo e nossa concepção moderna de nós mesmos são subprodutos da invenção de um mundo que está no papel”.

Até 2006, pode-se dizer que o vocábulo permanência é utilizado como apêndice, na expressão “acesso e permanência”, se considerarmos seu uso rarefeito na academia. Contudo, entre 2007 e 2012, verificamos que essa rarefação diminui, considerando que o vocábulo permanência aparece, independentemente da palavra acesso, em 78\% dos títulos. Por isso, entendemos ser possível sugerir que, nesse período, tais autores se arriscam na travessia de uma experiência instituinte, por passarem do uso da expressão "acesso e permanência" ao uso de permanência escolar como objeto em si e não mais ligado ao acesso. 


\section{Pontos de vista e horizontes}

Se há um horizonte para os objetivos desse trabalho, ele poderia ser formulado da seguinte maneira: compreender, nas publicações selecionadas, as formas de escrever sobre permanência escolar na EJA como experiências instituintes e tomá-las como constituídas de uma propriedade discursiva que se tensiona com o discurso naturalizado da evasão/fracasso escolar, a fim de dar materialidade e sentidos sobre o que vem a ser o permanecer na escola.

Não se trata de enaltecer as publicações aqui arroladas, em comparação a outras sobre fracasso escolar, evasão, abandono etc. Trata-se, sim, de anunciar percursos de pesquisadores - envolvidos ou não como professores ou gestores de uma unidade escolar — que tomam a temática da permanência como escolha quase inusitada, quase sem referências bibliográficas anteriores. É uma espécie de escolha por trilhar uma terra que foi impedida de existir, ou de ser vista, pela naturalizada e "[...] abissal desigualdade social brasileira”, como nos aponta, o sociólogo Jessé Souza (2003).

Para dizer sobre aquilo que reclama visibilidade — a permanência escolar — várias publicações tiveram que recorrer ao discurso instituído sobre evasão/fracasso escolar. Isto é, tornar a permanência escolar visível a partir do seu contrário, que ocupa de forma dominante o olhar dos pesquisadores, que têm na evasão e no fracasso escolar o objeto de investigação. O que vai ao encontro do que afirma Dominick (2013, p. 6) a partir de Castoriadis — as experiências instituintes não estão em "uma redoma, apartadas do instituído".

Parafraseando Larrosa (2001, p. 25), podemos dizer que várias das pesquisas selecionadas são lugares de experiências, nas quais o importante não foi a tomada de posição (a maneira de o autor se pôr); nem a o-posição (a sua maneira de se opor); nem a im-posição (a maneira de se impor); nem a pro-posição (a maneira de propor); mas, sim, a ex-posição, sua maneira de se ex-por, com tudo o que deve ter tido de vulnerabilidade e de risco para avançar em terreno ainda invisível academicamente.

Por isso, também assumimos o risco da experiência de redigir este ensaio, quando nos propusemos a interpretar o número crescente de publicações sobre permanência escolar, relacionando- as entre si e dando-lhes visibilidade, a partir de um lugar que é o nosso ponto de vista, isto é, a vista de um ponto de onde olhamos: o ato de escrever sobre permanência escolar como experiência instituinte. Nesse sentido, nosso ponto de vista implica admitir a emancipação pela escrita, no sentido de uma dimensão humana, como experiência capaz de produzir movimento em diálogo para fazer valer e proteger o direito à educação, como direito do homem. Conforme Bobbio (2004, p. 45): “O problema grave de nosso tempo, com relação aos direitos do homem, não é mais o de fundamentá-los, e sim o de protegê-los [...] para impedir que, apesar das solenes declarações, eles sejam continuamente violados".

De outra forma, nas publicações selecionadas, o horizonte da permanência escolar é um lugar em que se acumulam experiências instituintes na luta contra a naturalização dos maus tratos e do não reconhecimento social dos alunos de EJA (Carmo, 2010). Ou seja, um lugar no qual os docentespesquisadores se posicionam para reconhecer socialmente esse aluno; ou um lugar no qual os gestores-pesquisadores se posicionam para promover mudanças sistêmicas na instituição escolar, adequando-se assim à lei que rege a educação nacional.

Enfim, um horizonte em que permanência escolar se apresenta como símbolo da materialidade de um lugar discente, um “estar” na escola para aprender e não só para estar de corpo presente. E, também, como um lugar discursivo, de onde o pesquisador escreve e diz com o propósito de garantir e proteger o direito a uma educação de qualidade, diferentemente daquele lugar discursivo que se materializa na tentativa de garantir, a qualquer custo, apenas o fluxo escolar dos alunos.

Um horizonte que problematiza e questiona a visão da EJA como modalidade de "segunda linha" (Haddad, 2000), na medida em que os pesquisadores propõem e se expõem, de forma consciente ou não, a uma experiência da escrita sobre permanência na EJA, constituindo não só um 
desafio autoral na redação de uma experiência instituinte, no sentido dado por Linhares (2007), mas, principalmente, uma possível "virada epistemológica" do olhar sobre os maus tratos que jovens e adultos dos meios populares muitas vezes sofrem dentro da sala de aula ou nos ambientes coletivos da escola, gerando uma indignação contida que, muitas vezes, configura-se no motivo principal para a saída da escola (Carmo, 2010).

O vínculo entre indignação contida com os maus tratos vividos por alunos de EJA e a assunção da permanência escolar como objeto de pesquisa pode ser sustentado teórica e filosoficamente por Honneth (2003), quando este afirma que a tensão afetiva, provocada pelo sofrimento de humilhações no indivíduo, só pode ser dissolvida por ele à medida que reencontra a possibilidade da ação ativa e contínua fundada em práticas sociais de reconhecimento.

Portanto, ao dizermos que vários pesquisadores das publicações selecionadas têm um ponto em comum quando escrevem sobre realidades de maus tratos ou de reconhecimento social no mundo da escola/sala de aula, também podemos dizer que estes se inscrevem numa relação de emancipação de subjetividades, desafiando preconceitos instituídos em relação a jovens e adultos que retornam ou lutam por permanecer na escola.

Entendemos que as características metodológicas dos estudos que integram este ensaio têm mais de um ponto em comum porque, independentemente de acordos prévios e/ou conscientes, estão sob a recomendação metodológica de Paiva (2005, p. 8), baseada em "formas de compreender e apreender sentidos e necessidades de variados públicos que os buscam [programas e projetos]", bem como sob a de Moura (2006, p. 10), quando afirma: “[...] essa esfera educacional [deve ser vista] com identidade própria constituindo-se em um novo objeto de estudo que demandará um método específico".

Dessa forma, ambas as recomendações, articuladas à noção de reconhecimento social como ponto comum, conferem dimensão epistemológica distinta a essas pesquisas, porque, ao imergirem nas percepções e práticas dos sujeitos-alunos/professores pesquisados, problematizam a "falta de interesse" dos jovens, o "tempo longe da escola" dos adultos, o "medo das provas" de ambos, e adotam, necessariamente, uma concepção afirmativa sobre a atitude de jovens e adultos retornarem à escola sob a influência de uma ilusão fecunda como propõe Sposito (1993).

Tal horizonte nos faz pensar na experiência instituinte de escrever sobre permanência escolar na EJA também como discurso instituinte. E este mesmo discurso delineia uma fronteira, estabelecendo limites em relação a um discurso instituído ocupado com o que falta, isto é, com a "incapacidade" e "incompletude" desses jovens e adultos.

Com tais objetivos, pontos de vista e horizontes é que nos propusemos a construir este ensaio, sustentado por perspectivas paradigmáticas e epistemológicas, que subvertem o ordenamento de uma "subcidadania" de origem naturalizada (Souza, 2003) e reservada a esses jovens e adultos dos meios populares, cujo lugar na sala de aula é marcado pelo silêncio de seus modos de ver e experienciar o mundo em que vivem, conforme apontam Martins (2006) e Noro (2011).

Uma visão de mundo que foi escrita e está no papel sob um véu de naturalização, consequentemente, torna opaca uma realidade de jovens e adultos que não concluíram a educação básica. Portanto, conformam um paradigma epistemológico que exige restrições metodológicas severas, de modo a conduzir a escrita das experiências sob a perspectiva da permanência escolar. Um percurso sobre terras nunca dantes percorridas e não sobre terras já mapeadas por coordenadas que localizam apenas o que falta nesses sujeitos jovens e adultos considerados, pelo senso comum, como sujeitos desprovidos de saber, sujeitos "incompletos". 


\section{Mapas e percursos: diferenças entre os modos de escrever sobre a permanência e a evasão escolar}

Entendendo que a palavra discurso ${ }^{13}$, etimologicamente, contém a ideia de movimento, de correr ao redor, podemos dizer que a abordagem da experiência instituinte permitiu perceber os percursos que vários pesquisadores fizeram para escrever sobre permanência escolar, deixando visíveis em suas publicações três movimentos para se desviarem ou romperem com a forma naturalizada (instituida) de abordar a evasão escolar:

a- anunciar, de forma direta, a escolha por outro caminho, justificando-o de formas variadas, mas a partir da negação do caminho existente;

b- constituir "nichos de sentido" (Martins, 2006) ${ }^{14}$, como maneiras de dar sentidos, de aproximar, de delimitar domínios a partir de aproximações entre discursos de práticas pedagógicas e de gestão sobre permanência escolar;

c- perceber que o direito à educação de qualidade é um referente de interdiscurso que corresponde e se adequa melhor à expressão "garantir a permanência" do que àquela que diz "reduzir a evasão".

Consequentemente, pode-se dizer que o ponto de partida dos três movimentos encontrados nas publicações tem um pressuposto: garantir a permanência escolar não tem o mesmo significado de reduzir a evasão escolar.

Como sugerimos anteriormente, com base em Carmo (2010), há indícios de que o discurso da evasão é um discurso naturalizado que, historicamente, se constrói sob "causas" que em sua maioria recaem sobre o indivíduo que está na escola ou busca a escola. Tal naturalização sustenta-se em argumentos do senso comum tais como: o sujeito aluno evade porque trabalha ou porque não tem interesse em estudar ou porque não tem base de estudo.

Dessa forma, consideramos que a percepção desses três movimentos dos pesquisadores configurou o início deste trabalho, o que exige justificativa para a forma como está escrito e conduzido.

Conduzimos esse ensaio utilizando a noção de percurso, a partir de Michel de Certeau (1998). É curioso perceber a importância dos percursos na Idade Média. Conforme Certeau (1998, p. 205), os primeiros mapas medievais:

[...] comportavam só os traçados retilíneos de percursos (indicações performativas que visavam sobretudo peregrinações), com a menção de etapas a efetuar (cidades onde passar, parar, alojar-se, rezar etc.) e distâncias computadas em horas ou em dias, ou seja, em tempos de marcha.

Continuando, Certeau (1998, p. 205) faz um paralelo de "mapa" com a expressão ver concebida como um conhecimento da ordem dos lugares -, e de "percurso", com a expressão fazer concebida como ações espacializantes. Ao indagar-se qual seria a coordenação entre um fazer e um ver na linguagem natural, em que o primeiro domina de maneira tão evidente, ele mesmo responde:

A questão toca, finalmente, na base dessas narrações cotidianas, a relação entre o itinerário (uma série discursiva de operações) e o mapa (uma descrição redutora

\footnotetext{
${ }^{13}$ Etimologia de discurso vem do latim discursus, particípio passado de discurrere, "correr ao redor", metaforicamente "lidar com um assunto por vários pontos de vista", formado por dis-, "fora", mais currere, "correr". O sentido de "manifestação oral formal" é do século XVI. Recuperado em 20 fev. 2011, de http://origemdapalavra.com.br/palavras/discurso

${ }^{14}$ Martins cunha a expressão "nichos de sentidos" a exemplo do que Orlandi (1996) chama de "sítios de significância".
} 
totalizante das observações), isto é, entre duas linguagens simbólicas e antropológicas do espaço. Dois polos da experiência. Parece que, da cultura "ordinária” ao discurso científico, se passa de um para o outro.

A partir de outro trecho do trabalho de Certeau (1998, p. 204) outras informações contribuem para fundamentar o valor que o autor dá a noção de "percurso":

[...] tomando-se o "mapa" sob a sua forma geográfica atual, parece que no decurso do período marcado pelo nascimento do discurso científico moderno (séculos XV-XVII), ele se foi aos poucos separando dos itinerários que constituíam a sua condição de possibilidade.

Nossa intenção não é prolongar a discussão que Certeau promove com suas noções de "mapa" e "percurso", mas, sim, aderir ao nosso trabalho os recursos metafóricos que ele utiliza para tratar do percurso da arte do fazer cotidiano. Para Certeau (1998, p. 200), todo relato é um relato de viagem, uma prática do espaço, na qual "[...] a sutil complexidade dos relatos, cotidianos ou literários, são nossos transportes coletivos, nossas metaphorai”.

Parece-nos que as publicações em torno da expressão permanência na educação, nos últimos seis anos (2007-2012), estão nesse processo de fazer-ver e, vice-versa, ver-fazer. Isto é, os relatos de experiências, as tentativas de sistematizações de experiências existentes, de reordenações históricas, de reordenações conceituais, podem ser consideradas experiências instituintes e, consequentemente, discursos instituintes que nos permitem, por pouco que seja, praticar "[...] a sutil complexidade dos relatos" como percursos por onde nossas ideias, ao serem escritas, tornam-se transportes mentais coletivos de uma nova forma de abordar um dos princípios da Constituição Federal de 1988 em seu Art. 206, princípio I: "igualdade de condições para o acesso e permanência na escola" (BRASIL, 2004).

Ao dizer que as publicações em torno da permanência escolar na EJA nos permitem "por pouco que seja" praticar "a sutil complexidade dos relatos" não significa uma pseudo-humildade intelectual, mas, sim, uma restrição metodológica de abordagem sobre o nosso objeto de pesquisa, imposta pela pequena quantidade e dispersão das 31 publicações produzidas entre 1998 e 2012. Por isso, entendemos que a noção de experiência instituinte é promissora para um primeiro diálogo entre as publicações, considerando que não encontramos, até novembro de 2012, qualquer publicação com esse objetivo.

Entretanto, admitir tal restrição metodológica, imposta pela pequena quantidade e dispersão das publicações, implica afirmar que, nesse ensaio, não podemos e nem devemos estar na mesma perspectiva, por exemplo, da pesquisa de Bragança (2008) A produção do saber nas pesquisas sobre o fracasso escolar (1996-2007) ${ }^{15}$, que reuniu mil publicações produzidas em doze anos, utilizando $326 \mathrm{em}$ sua dissertação. Trata-se, na concepção da autora, de um "número razoável” para o período:

Esta investigação resultou em uma coleta de mil textos e a posterior criação de um banco de dados sobre o tema "fracasso escolar". Para esta dissertação, foram selecionados inicialmente trezentos e vinte e seis artigos, procedentes dos recortes realizados pelas análises utilizando o método indutivo. Esta meta de mil artigos foi pensada pelo grupo de pesquisa como sendo um número razoável e representativo da produção sobre o assunto, considerando o período de tempo de dez anos aproximadamente (Bragança, 2008, p. 21).

Não podemos estar na mesma perspectiva pela óbvia e gritante diferença numérica. Mas também não devemos fazê-lo, o que é mais importante, porque intuímos que escrever sobre a permanência escolar tem o sentido de uma experiência instituinte que luta por seguir outro caminho. Um

15 Entende-se que fracasso e evasão escolar pertencem a uma mesma rede semântica negativa. 
caminho para se emancipar do seu "contrário": o discurso instituído da evasão, do abandono, do desinteresse, do fracasso escolar, entre outros, mapeado não apenas por Bragança, em 2008, mas também por Patto et al. (2004) em O estado da arte da pesquisa sobre o fracasso escolar (1991-2002): um estudo introdutório e Amaral (2010), em História de (re)provação escolar: vinte e cinco anos depois, e, ainda, talvez, por outros que desconhecemos.

Esse é um exemplo de litígio, conforme aponta Dominick (2013, p. 6), no qual as experiências instituintes de escrever sobre permanência escolar se desdobram em enfrentamentos que se infiltram nas tramas instituídas. Isto porque não basta agir em prol da permanência escolar. É preciso escrever sobre elas, assumindo "o compromisso de desocultar opressões pouco visíveis, negações silenciadas".

\section{Percursos dos relatos sobre permanência escolar}

As categorias propostas a seguir conformam um ponto de vista, entre tantos outros possíveis, na sua forma de organizar as escritas de experiências instituintes sobre permanência escolar. Ainda assim, este ensaio não está isento de intencionalidade ao assumir como ponto de vista a utopia de uma educação pública de qualidade, gratuita e obrigatória para todos como um direito, como formulada por Anísio Teixeira e desejada por seus seguidores.

Outra observação diz respeito à forma generalizada como iremos tratar os destinatários referidos nas publicações selecionadas. Serão chamados de jovens e adultos dos meios populares, mesmo que algumas pesquisas lidem com alunos que não tenham esse perfil.

\section{Primeiro percurso de categorização dos relatos presentes nas publicações selecionadas: a permanência es colar como símbolo de mudança na forma de pesquisar sobre jovens e adultos dos meios populares}

Uma das contribuições de uma experiência instituinte é nos colocar em estado de reflexão, sem a ilusão de uma consciência plena do objeto em questão, mas capaz de perscrutar o lado invisível, por meio do "pensamento impensado" de Bourdieu (1988), de um outro objeto que, naturalizado, se impõe como dominante e de forma opaca na sua maneira de observar jovens e adultos dos meios populares na sua relação com a escola. Parece-nos ser este o caso da ampliação do uso da expressão permanência escolar como capaz de conter um certo simbolismo de ruptura em relação ao discurso da evasão escolar, em especial no discurso acadêmico.

Além do fato de $80 \%$ das publicações sobre permanência escolar estarem concentradas em seis anos - em relação aos onze anos anteriores - outro fato chama a atenção: oito pesquisas enunciam a permanência associando-a simbolicamente a uma ruptura ou a uma visão contrária à abordagem dos estudos sobre evasão: Lenskij (2006); Santos (2007); Gusmão (2010); Mileto e Carmo (2010); Nunes (2010); Zago (2010) ${ }^{16}$; Noro (2011); e Oliveira (2011).

Essa associação simbólica parece necessária para fazer ver algo que não existe, a partir da perspectiva de um discurso naturalizado, o da evasão/fracasso escolar. Uma parte dessas publicações recorre à metáfora da visão para constituir esse lugar de dizer, lugar este ainda invisível para muitos autores.

\footnotetext{
${ }^{16}$ Incluímos o trabalho de Nadir Zago sobre ensino superior porque o artigo é produto de pesquisa que desenvolve há alguns anos sobre escolarização nos meios populares, voltada especialmente para trajetórias escolares nos ensinos fundamental e médio.
} 
Noro (2011), na pesquisa no Curso PROEJA ${ }^{17}$ Técnico em Administração, no campus Sapucaia do Sul do IFSUL Rio-Grandense, faz uma opção por um foco "otimista" com aspas: No primeiro ano de implantação de nosso curso PROEJA surgem muitas inquietações relacionadas ao alto índice de evasão de alunos, sendo que começamos a refletir em conjunto sobre suas possíveis causas e a relação da evasão com a forma de acesso ao curso. Mas como pretendia realizar uma pesquisa "otimista", preferi focalizar minha pesquisa na permanência, isto é, parodiando Jaqueline Moll (2010, p. 135) nos estudantes que "entram, permanecem e aprendem" (Noro, 2011, p. 24 - grifo nosso).

Noro (2011. p. 39), ainda parafraseando Moll, ao discorrer sobre o PROEJA e seus desafios, "[...] conclui dizendo da necessária mudança na forma como vemos estes estudantes para que entrem, permaneçam e aprendam".

No artigo Propostas de conversão do olhar sobre a EJA: pesquisando o 'enigma' da permanência, Mileto e Carmo (2010, p. 1) deixam evidente a metáfora da visão, a partir da perspectiva sociológica bourdiesiana:

Os trabalhos [...] têm em comum a adoção de uma perspectiva ainda pouco frequente no campo da EJA: objetivaram estudar como foram construídos processos de permanência e sucesso escolar pelos estudantes dessa modalidade de educação. Apesar da utilização de diferentes fundamentações teórico-metodológicos, as duas pesquisas seguiram o princípio denominado por Bourdieu como conversão do olhar, intentando questionar se o modo mais recorrente de tratar um problema seria de fato o modo mais apropriado.

Nunes (2010, p. 30), ao pesquisar alunos do ensino médio estadual regular noturno, de jovens e adultos egressos de um curso em equivalência ao ensino fundamental na modalidade EJA da rede municipal de ensino de Florianópolis, utiliza a palavra prisma - cristal que decompõe a luz cujo sentido figurado é ponto de vista, conforme Aulete (2011) — para negar a perspectiva da evasão/reprovação, ampliando assim o sentido afirmativo de sua escolha pela permanência e aprovação como objeto de pesquisa:

Pela segunda via, por um lado, pretende-se trazer à discussão o reconhecimento do ensino médio regular como outro espaço de sujeitos da EJA e, por outro, analisar o resultado educacional não pelo prisma da evasão e reprovação, mas pelo da permanência e aprovação nos estudos que, como considera Charlot (2000), são uma forma de leitura positiva da realidade, uma postura epistemológica e metodológica.

Outros recorrem à metáfora do "novo como desafio" anunciado como uma escolha necessária para realizá-lo em função de ser um movimento de contracultura, de aventura por lugares desconhecidos, de novas possibilidades, de sinais positivos e oxigenantes, mas não o fazem sem antes denunciar o lugar estagnado, mas dominante da "cultura da evasão".

Santos (2007, p. 10), pesquisando EJA no ensino fundamental de uma escola pública do Distrito Federal, estrutura uma argumentação que parte da denúncia para o anúncio de um movimento em direção à garantia da permanência escolar na EJA. Segundo a autora, a pesquisa: [...] inicialmente denuncia as relações sociais que contribuem com o abandono do educando e, ao mesmo tempo, levanta sinalizações que anunciam a possibilidade de que o sistema escolar pode e deve fazer o movimento contrário, garantindo a permanência.

\footnotetext{
${ }^{17}$ Programa Nacional de Integração da Educação Profissional à Educação Básica na modalidade de Educação de Jovens e Adultos (PROEJA).
} 
Santos (2007, p. 42), a partir de uma consulta ao Dicionário Aurélio da palavra permanência, cujo significado é "[...] conservar-se, continuar a ser, continuar a existir, perseverança, constância [...]", associa a compreensão do que está escrito a uma educação "oxigenante" como novas possibilidades para a EJA: "Busco todo esse significado no intuito de, durante a pesquisa, compreender melhor se o contexto em que me inseri sinaliza uma educação oxigenante que aponta novas possibilidades para a Educação de Jovens e Adultos".

Acentuando que a "nova possibilidade" parte de um movimento de contracultura, indagamos: quais as múltiplas determinações que causam a permanência de uma turma de Educação de Jovens e Adultos em uma cultura predominante de evasão?

Zago (2010, p. 226), pesquisando sobre a longevidade escolar de alunos das camadas populares que alcançam o ensino superior, compartilha desse caráter "predominante" da evasão/fracasso escolar quando situa sua pesquisa numa linha inovadora:

Nas últimas duas décadas, estudos no campo da sociologia da educação produzidos no Brasil e no exterior vêm fornecendo indicadores teóricos importantes para problematizar o que tem sido chamado "longevidade escolar", casos "atípicos" ou "trajetórias excepcionais" nos meios populares. Trata-se de uma linha inovadora, haja vista ser relativamente recente na disciplina o interesse pelos casos que fogem à tendência dominante, voltada para o chamado fracasso escolar nesses meios sociais (grifo nosso).

Logo, de acordo com Zago (2010, p. 236), tal linha inovadora de pesquisa está associada à urgência de se "Estudar essa população para entender as transformações nas demandas e nas práticas escolares, assim como no perfil dos estudantes na sociedade contemporânea", afirmando ser esta uma "[...] necessidade para a pesquisa e as políticas educacionais em todos os níveis de ensino".

Oliveira (2011, p. 15), que investigou uma turma de alfabetização de EJA localizada em uma escola municipal de Belo Horizonte - nesse movimento de oposição à tendência dominante de estudos sobre a evasão — , usa um eufemismo para justificar sua escolha pela investigação com foco na permanência escolar, dizendo que a interrupção dos estudos tem uma "complexidade" que deve ser evitada:

Levando em consideração a complexidade do fator interrupção dos estudos, propusemo-nos uma investigação junto a sujeitos da EJA tendo como foco estudantes da etapa da alfabetização que permaneceram no ambiente escolar na passagem do ano letivo de 2009 para 2010 (grifo nosso).

Para concluir as menções à metáfora do "novo como desafio", Lenskij (2006, p. 16) mostra que o desafio da mudança de olhar sobre os sujeitos de EJA está vinculado a uma "metamorfose" nas preocupações do pesquisador, uma possível variação da "conversão do olhar" de Bourdieu (1998): Agora, como aluna do Mestrado em Educação, ao reler os [meus] escritos anteriores à luz de um contexto político nacional e internacional de luta pela proteção dos direitos humanos, e ações afirmativas do direito à educação, minhas preocupações anteriores se metamorfosearam. De dados estatísticos que demonstravam a exclusão na escola, minha preocupação se deslocou para questões relativas ao direito à permanência na escola [...] Da investigação sobre a evasão — da ordem do quantitativo, como expressão da exclusão escolar e social - passei para a outra ponta desta dualidade, a permanência na escola, com a intenção de conhecer as estratégias utilizadas pelos operadores do ensino para cumprir o princípio constitucional do direito à educação [...]. 
O trabalho de Lenskij (2006, p. 22), um estudo de caso realizado em uma escola pública de Porto Alegre - ao avançar com as questões do direito à educação em direção à "caixa preta", ou seja, o processo decisório subterrâneo que perpassa práticas pedagógicas de aprovação/reprovação ou de reconhecimento/não reconhecimento social dos alunos — tornou-se, para a autora, uma aventura intelectual a partir do momento em que suas preocupações sofrem metamorfose:

Esta dissertação é o produto de uma pequena aventura intelectual, na qual ousei trilhar caminhos que sempre estiveram ali, mas que muito recentemente começaram a ser descobertos: a compreensão das concepções de Direito à Educação e de Justiça realizada na escola, expressas e/ou praticadas pelos operadores do ensino, investidos na condição de juízes, ao decidir sobre a permanência e aprovação/reprovação de crianças e adolescentes nas escolas.

Poder-se-ia contrapor a todo esse simbolismo de ruptura afirmativa da permanência escolar, presente nas publicações mencionadas, o fato de a permanência na escola ser princípio constitucional desde 1988, ratificado na LDBEN n. 9394/96. Porém se, naqueles anos, a palavra permanência já estava investida de legalidade e, portanto, institucionalizada, por que só a partir de 2007 esse simbolismo emerge em várias publicações?

Uma possibilidade nos é apresentada por Oliveira e Araújo (2005, p. 5) quando optam por “[...] contrapor os notáveis ganhos obtidos no acesso à escola aos desafios deles decorrentes [...]" e percebem que "[...] os obstáculos à democratização do ensino foram transferindo-se do acesso para a permanência com sucesso no interior do sistema escolar" (Oliveira; Araújo, 2005, p. 10).

Por isso, entendemos ser emblemático observar a apropriação que Gusmão (2010) faz do trabalho de Oliveira e Araújo (2005). Com uma escrita determinada, se não enfática, a autora afirma (Gusmão, 2010, p. 32): "Na década de 1980, passou a vigorar o segundo significado que circulou simbolicamente como representação da qualidade: a permanência".

Mas, se observarmos o parágrafo abaixo, de Oliveira e Araújo (2005, p. 10), parafraseados por Gusmão (2010), não se encontra a palavra permanência, apenas a "ideia de fluxo" como um segundo indicador de qualidade na década de 1980.

Quando foi eliminado o exame de admissão (Lei n. 5.692/71), essa passagem, do ponto de vista formal, tornou-se um pouco mais fácil. Porém, teve início um novo tipo de seletividade que deu origem a um outro conceito de qualidade, agora relacionado à ideia de fluxo, definido como número de alunos que progridem dentro de determinado sistema de ensino. Assim, no final dos anos de 1970 e nos anos de 1980, um segundo indicador de qualidade foi incorporado ao debate educacional no Brasil. A partir da comparação entre a entrada e a saída de alunos do sistema de ensino, era medida a qualidade da escola. Se a saída se mostrasse muito pequena em relação à entrada, a escola ou o sistema como um todo teria baixa qualidade (grifos nossos).

É assim que Gusmão (2010) atualiza a "ideia de fluxo" para a "ideia de permanência”, como um significado que passa a circular simbolicamente como indicador de qualidade na década de 1980. Tanto a substituição da "ideia de fluxo" para a "permanência", como o fato de atribuir-lhe um caráter simbólico são exemplos de escolhas que a pesquisadora assume sem dialogar com outras pesquisas, cujo objeto é a permanência escolar. Assim, ao preferir a expressão permanência escolar para vinculá-la à luta pela qualidade da educação, evitando a expressão fluxo escolar, que sugere uma relação matemática de entrada e saída de alunos, Gusmão (2010) realiza uma experiência instituinte que corresponde ao ato de subverter o sentido da expressão fluxo escolar. 
Por isso, é interessante destacar que essas “irrupções” simbólicas, apesar de acontecerem de modo disperso entre os pesquisadores das publicações selecionadas, convergem para aquilo que se tornou a ideologia dos direitos humanos. Como diz Lefort (1981 apud Reis, 1998, p. 89), contemporaneamente, a noção de "direitos humanos" transcende o contexto burguês que lhe deu vida para tornar-se uma dimensão simbólica da política que constitui uma conquista da humanidade. Tais direitos conformam não uma realidade, mas princípios que reinventam a democracia a cada instante, na sociedade das últimas duas décadas, genericamente denominada complexa ou da informação. Para Melucci (2001), essas ações alteram a lógica dominante no terreno simbólico, questionam a definição dos códigos e a leitura da realidade, anunciando que a criação de novos códigos e novos símbolos culturais é possível.

Dessa forma, pensamos que, nesse momento de trânsito entre a conquista do "acesso" e ampliação da luta pelo direito à educação, a emergência simbólica do termo permanência escolar nos mostra uma tendência de associá-la a uma busca por educação de qualidade. Nesse sentido, tanto pela dispersão, quanto pela convergência de formas de escrever experiências instituintes sobre permanência, entendemos, mais uma vez, ser possível associá-la às "categorias do pensamento impensado" de Bourdieu (1988), considerando que estas procuram elucidar questões sobre o mesmo objeto de uma forma diferente.

Assim, continuando a tomar o "pensamento impensado" para produzir categorias com as quais poderemos delimitar nosso pensar, aventa-se uma hipótese embrionária de que tal dispersão e convergência tratam-se de uma formação discursiva em construção, nos sentidos dados de forma complementar por Foucault (1997) e Orlandi (2005), a partir de uma possível e impensada construção coletiva do conceito de permanência escolar.

Para Orlandi (2005), a noção de formação discursiva ajuda a compreender o processo de produção de sentidos se entendida como uma formação ideológica — ou seja, a partir de uma posição dada em uma conjuntura sócio-histórica —-, delimitando o que pode e deve ser dito conforme a posição de quem fala (ou escreve). As formações discursivas podem ser vistas como nichos de sentidos, configurações específicas dos discursos e suas relações dadas pelas posições ideológicas colocadas em jogo no processo sócio-histórico em que as palavras são produzidas.

De forma diferente, mas complementar, Foucault (1997, p. 134) vai nos dizer que a formação discursiva "[...] disseca o plano geral das coisas ditas no nível específico dos enunciados", sendo que tais enunciados devem ser observados pelas regularidades que os caracterizam, e não pelo "[...] nível gramatical das frases, ou lógico das proposições, ou psicológico da formulação”. Assim, para Foucault, um gráfico, um regimento, uma ata, um desenho, uma placa de inauguração, uma matrícula, um protocolo de experiência, uma música, uma foto, um hábito, uma atividade de aula, também são enunciados.

Nesse sentido, a apropriação de alguns aspectos das noções de formação discursiva formuladas por Orlandi e Foucault compôs um recurso necessário para constituirmos um aparato de leitura dos conteúdos das publicações selecionadas com o propósito de melhor caracterizar o que estamos entendendo por experiência instituinte de escrever sobre permanência escolar, evidenciando a dinâmica de relações e "nichos de sentidos" que tais escritas vão estabelecendo para garantir e proteger o direito à qualidade da educação e, portanto, da permanência escolar.

Segundo percurso de categorização dos relatos presentes nas publicações selecionadas: a permanência escolar como lugar de agir, refletir e escrever sobre o direito à qualidade na educação para jovens e adultos dos meios populares

Anteriormente, dissemos que os pesquisadores das publicações selecionadas escrevem sobre realidades de maus tratos ou de reconhecimento social no mundo escola/sala de aula que os alunos 
jovens e adultos precisam enfrentar. Por isso, se inscrevem numa relação de emancipação de subjetividades, desafiando preconceitos instituídos por meio de uma experiência instituinte de escrever sobre permanência escolar. Isto posto, resta-nos detalhar como agem, refletem e escrevem sobre tais realidades por meio de enunciados de uma formação discursiva da permanência escolar associada à luta por uma educação de qualidade.

Para tanto, será necessário tomar emprestado alguns aspectos da noção de enunciado de Foucault (1997) a fim de organizarmos as práticas mencionadas nas publicações, percebendo-as como instituintes. Resumidamente, para esse autor, o enunciado é uma função ${ }^{18}$ que existe a partir das relações simbólicas que dão sentido aos modos de ser e estar no mundo. Por isso, é possível imaginar o enunciado como um lugar, isto é, lugar de enunciação, lugar de onde se fala (ou escreve), cujas relações simbólicas delimitam o que, o como, o quando, o com quem se fala (ou escreve).

Foucault $(1997$, p. 133) nos apresenta o enunciado como:

[...] uma função que se apoia em conjuntos de signos, e que requer, para se realizar, um referencial (que não é exatamente um fato, um estado de coisas, nem mesmo um objeto, mas um princípio de diferenciação); um sujeito (não a consciência que fala, não o autor da formulação, mas uma posição que pode ser ocupada, sob certas condições, por indivíduos diferentes); um campo associado (que não é o contexto real da formulação, a situação na qual foi articulada, mas um domínio de coexistência para outros enunciados); uma materialidade (que não é apenas a substância ou o suporte da articulação, mas um status, regras de transcrição, possibilidades de uso ou de reutilização).

Como é possível observar, tanto a noção de formação discursiva quanto a de enunciado, a partir de Foucault e Orlandi, conformam um dispositivo teórico de interpretação do mundo humano mediado pela linguagem, portanto, só tomam forma se os requisitos do dispositivo forem atendidos.

Tomando por base as publicações selecionadas, vamos, nesse momento, organizar trechos de suas escritas de forma a verificar se atendem aos requisitos da função enunciativa da permanência escolar como um lugar de dizer a respeito de práticas pedagógicas e gestoras diferenciadas.

Primeiro requisito, um referencial: ser um princípio de diferenciação

Como princípio de diferenciação necessário para conceber a permanência escolar como uma função enunciativa, compreendemos que esta seja a mudança na forma de observar o aluno jovem e adulto, pois possui um caráter epistemológico, isto é, na forma de produzir conhecimento sobre a relação desses sujeitos jovens e adultos dos meios populares com o conhecimento escolarizado.

Ao observar sem preconceito trajetórias irregulares dos alunos da EJA, o pesquisador tem oportunidade de imergir em um mundo ainda desconhecido e dar-lhe visibilidade, caracterizando-o de forma a compreendê-lo e interagir pedagogicamente de maneira mais adequada às suas peculiaridades.

Klinski (2009) estudou a respeito de alunos que já haviam completado o ensino regular, mas que ingressaram e permaneceram no PROEJA do IFSUL Rio-Grandense campus Charqueadas. Um dos motivos teria sido a falta de opção formativa no município e a baixa qualidade do ensino médio já cursado; no entanto, para estes estudantes, o IFT (Instituto Federal Tecnológico), reconhecido

\footnotetext{
${ }^{18}$ Entender o enunciado como função significa dizer que é possível haver uma equivalência entre frase e enunciado, entretanto, a equivalência está longe de ser completa porque há enunciados que não correspondem à estrutura linguística das frases, por exemplo: uma árvore genealógica, um livro contábil, as estimativas de um balanço comercial, uma curva de crescimento, uma pirâmide etária são enunciados, mas não são frases (Foucault, 1997, p. 93)
} 
como uma instituição de excelência em educação profissional tornou-se um meio de concretizar ou de construir projetos de vida.

Esse modo de conduzir os estudos de forma não linear, sem se importar com uma escolarização crescente e sucessiva ao modo do preconizado pelas famílias economicamente favorecidas, é observado também por Carmo et al. (2012), ao pesquisar a EJA de um pequeno município da Região Noroeste do Rio de Janeiro. Senhoras estudiosas de uma turma do $5^{\circ}$ ano do ensino fundamental, no momento da avaliação final, respondiam as questões com o firme propósito de serem reprovadas, de modo a permanecerem na mesma turma e com a mesma professora. Silva (2009) denomina essa situação de permanência prolongada e a observa como um problema característico de alunos com dificuldade de aprendizagem. Mas, como vimos no exemplo acima, pode ser uma estratégia para manter a convivência em um ambiente de conhecimento sem a exclusiva preocupação de concluir o curso e obter a certificação.

Nunes (2010, p. 105) contribui para esse argumento, mencionando que “[...] enquanto para a faixa etária até os 14 anos a permanência nos estudos tem a faceta de cumprimento de obrigações legais, para a faixa de jovens e adultos, característica comum a todos os sujeitos neste estudo, essa obrigação não existe". Nunes constatou o fato de nenhum dos seus entrevistados do ensino médio noturno terem mencionado que se sentiam na obrigação de permanecer estudando como um dever não cumprido.

No que diz respeito às estratégias para permanecer na escola, Mileto (2009, p. 71) afirma que uma delas é buscar "[...] uma maior amplitude das relações humanas nos espaços escolares, incluindo não apenas aspectos cognitivos, abrangendo igualmente os aspectos afetivos". Citamos aqui um depoimento da dissertação de Mileto, exemplificando um dos motivos para permanecer na escola:

[Pergunta: O que foi mais importante para que você não desistisse de estudar aqui no PEJA? A escola, a turma, as amizades, os professores, o que você achou que foi assim mais importante?]

[...] Porque na M [faz referência a uma tentativa de voltar a estudar, há aproximadamente 20 anos, em uma escola estadual de Ensino Supletivo] é totalmente diferente. Lá, lá é vários professores... é o $2^{\circ}$ tempo, tem o $3^{\circ}$ tempo é o $1^{\circ}$ tempo, aquele negócio todo... e ali, os professores dali não são iguais a vocês. Vocês conversam com a gente. Se a gente não entendeu, vocês explicam várias vezes para a gente e passa a semana toda o mesmo trabalho até "encaixar" na nossa mente. Lá não. Lá eles dá a matéria nova, assim ó... naquela hora, naquela hora mesmo eles te passam um trabalho, quem entendeu, entendeu. Quem não entendeu, não entendeu, que se dane. Eles lá não esquentam com nada. Mas aqui não, eu achei que... poxa... Os professores daqui... Vocês são excelentes, sabe? Vocês são assim... Vocês se preocupa mais... com os alunos, não se preocupa [apenas] em eles aprenderem não, se preocupa assim também com o comportamento deles, como eles... como pessoa. (Rita, 50 anos, turma 162/2008, não era aluna PEJA 1, entrevista individual).

De forma complementar, Viana (1998, p. 148), autora do estudo mais antigo que encontramos sobre longevidade escolar em famílias de camadas populares, apresenta outro depoimento em que a aluna faz uma escolha, não para mudar de escola, mas para mudar de uma turma para outra que ficava ao lado da que estudava, porque, nesta última, havia clima para aprender e, portanto, para permanecer na escola:

Uma vez aceita na $4^{a}$ série, Catarina teve que enfrentar um novo problema: a turma na qual ingressara não oferecia as mínimas condições para a aprendizagem. A sala de aula "era uma bagunça, uma baderna, um inferno", comenta. E continua: “eu não lembro quem era a professora, nem imagino... na minha mente eu não tenho o rosto dela!". Por iniciativa própria, ela começou, então, a observar o funcionamento de uma sala de aula ao lado da sua, 
onde o clima era inteiramente outro; onde "não tinha bagunça, a professora falava baixinho". Após conversar com a diretora da escola, conseguiu ser transferida para a classe desejada (Viana, 1998, p. 148).

Cruz (2011), em pesquisa em uma escola de EJA de ensino fundamental de Belo Horizonte, acredita que o aluno dessa modalidade "[...] consegue permanecer na escola, dentre outras razões, [...] porque possui uma relação diferenciada com o saber e com a escola”. Entretanto, destaca o enfrentamento necessário para estabelecer essa relação com o saber a fim de superar as adversidades, dar sequência às atividades e seguir seu curso (Pais, 2003, p. 75 apud Cruz, 2011, p. 54):

Se o retorno à escola configura uma tomada de decisão difícil, permanecer nela exige dos referidos sujeitos um esforço ainda maior. Em grande medida eles/elas precisam agir como a "massa de água que, no leito do rio, se insinua, girando à volta de qualquer obstáculo, erosionando-o, enfrentando-o".

Nesse sentido, garante Viana (1998, p. 277), “[...] a permanência dos estudantes das camadas populares no sistema escolar, quando alcançada, realizar-se-ia sob o 'fio da navalha', em outros termos, na corda bamba".

Rios Neto et al. (2010, p. 23), ao analisarem a evolução de indicadores educacionais no Brasil, apontaram para a influência do gênero sobre a permanência escolar: "[...] nota-se que as mulheres têm índices mais altos de permanência nas escolas do que os homens em todo período analisado [1981 a 2008]", acrescentando que "esta é uma discussão necessária para perceber como a permanência [e o acesso] ocorrem de modos diferenciados entre diferentes grupos sociais no Brasil". (Rios Neto et al., 2010, p. 10).

Curioso observar que Haddad (1987), no Estado da Arte do Ensino Supletivo no Brasil, já recorre à diferença de gênero para explicar o predomínio do masculino nos exames de $1^{\circ}$ e $2^{\circ}$ graus: Até o final da década de 70 todas as pesquisas indicavam o predomínio de candidatos do sexo masculino para os exames de $1^{\circ}$ e $2^{\circ}$ graus em níveis próximos a $60 \%$. A explicação para este fato residiria em que, sendo os homens a maioria da população economicamente ativa, apresentariam maiores necessidades de escolarização para participar do mercado de trabalho (Velloso et al., 1977). Outra explicação seria decorrente de uma maior permanência de elementos do sexo feminino na escola regular, enquanto os meninos evadem-se mais cedo, pois também ingressam mais cedo no mercado de trabalho (entre 11 e 15 anos), o que lhes tira o tempo disponível para a escola regular. (Gatti, 1982, p. 33).

Esta influência de gênero é comprovada empiricamente por Silva e Gama (2008, p. 8), em um estudo na rede pública de ensino do município do Rio de Janeiro entre 1975 e 1995, no Programa de Educação Juvenil (PEJ), mostrando que "A mobilização das meninas no sentido de maior permanência na escola e de completar a escolaridade tem sido uma realidade neste período de vinte anos".

Segundo requisito, um sujeito: ser uma posição que pode ser ocupada, sob certas condições, por diferentes indivíduos

Como lugar de enunciação (vetor do lugar e do tempo de onde se fala ou escreve), no caso da permanência escolar, entendemos que sejam três as posições que podem ser ocupadas, sob certas condições, por diferentes indivíduos: a posição de pesquisador, a posição de professor/gestor e a posição de aluno. 
A permanência escolar na Educação de Jovens e Adultos DOSSIE EJAll

Os docentes, gestores e discentes produzem conhecimento e têm autoridade para ocupar posições de enunciação, pois são eles os operadores da educação que podem, devem e fazem a permanência escolar acontecer. Vale ressaltar que o pesquisador, pela função que exerce, tem posição privilegiada para organizar sua escrita e disseminar o direito e as práticas dessa permanência. É o pesquisador que se interessa por ela que pode e deve dar visibilidade ao que impede e ao que incentiva os anseios e as realizações que resultam em permanência na escola.

Explicitamos, aqui, quatro exemplos extraídos das publicações selecionadas nas quais é possível identificar (marcado em negrito nas citações) o caráter de visibilidade sobre uma realidade que se mantém invisível por causa do excesso de visibilidade ao que falta, nesses jovens e adultos dos meios populares:

1- Martins (2006, p. 18), em seu trabalho em uma turma de EJA no município de Blumenau, faz a seguinte pergunta: “a sala de aula é um lugar de silêncio?”. Sua questão faz referência a um exato momento em que, também como professora da turma, realiza sua investigação:

"Tomávamos notas no diário de campo, enquanto faziam a atividade. Percebemos que falavam muito baixo, cochichavam enquanto materializavam alguns sentidos sobre escola. Um trecho do diário de campo elucida este momento: Então resolvi cochichar também, e falhei-lhes: 'Gente, não precisa falar tão baixinho cochichando, tá?' Muitos risos do grupo preencheram aquele silêncio".

2- Um outro exemplo, a partir de Santos (2007, p. 42), mostra como um viés retórico, considerado inadequado para o gênero acadêmico, torna-se adequado face ao esforço necessário para trazer à tona questões quase óbvias: "Quero que o leitor compreenda bem o significado desta permanência... Refletindo comigo, durante a caminhada, se esta permanência é apenas a presença física do aluno em sala de aula".

3 - Rocha (2004, p. 5), que pesquisou sobre jovens e adultos de dois cursos do ensino médio noturno numa Escola Estadual de Ensino Médio Profissionalizante do Paraná, apresenta uma contradição entre as percepções docente e discente a respeito da condição noturna de aprendizagem: Observa-se que diante de alguns relatos de profissionais da escola, a menção sobre o aluno que trabalha, impõe-se à necessidade de compreensão de vínculos mais frágeis que estes estabelecem com o processo de escolarização, gerando por parte da equipe escolar práticas de ensino mais facilitadas mesmo em nome da sua permanência na escola.

Pode-se acrescentar por outro lado que os alunos manifestam a vontade de não serem considerados alunos trabalhadores cansados, que gostariam de regras e exigências mais claras, acrescentam que há falta de espaço para a participação.

4 - Da pesquisa de Lenskij (2009, p. 22), citada anteriormente, julgamos necessário repetir um trecho pela visibilidade que dá sobre atribuições veladas dos operadores de ensino na escola, quando objetiva explicitar:

[...] a compreensão das concepções de Direito à Educação e de Justiça realizada na escola, expressas e/ou praticadas pelos operadores do ensino, investidos na condição de juízes, ao decidir sobre a permanência e aprovação/reprovação de crianças e adolescentes nas escolas.

Estes e outros exemplos mais poderiam ser enumerados para demonstrar a pluralidade e por que não - a vitalidade das ideias enunciadas de uma posição sob certas condições, mas ocupada por diferentes pesquisadores que estão repensando as formas de olhar esses jovens e adultos na escola, em sala de aula, para que o direito à educação e à permanência se torne realidade para todos. 
Terceiro requisito, um campo associado: ser um domínio de coexistência para outros enunciados

O terceiro requisito - ser um campo associado — transcende o contexto do enunciado em si para ser um domínio de coexistência para outros enunciados com os quais opera como grupos de enunciados na delimitação da formação discursiva. Isto é, conjuntos de performances dos signos que estão ligados no nível dos enunciados.

No caso da permanência escolar e dos pesquisadores aqui arrolados, entendemos que aquela se configura como um domínio de coexistência de enunciados que se referenciam mutuamente, no sentido de se apoiarem em processo de sustentação do que escrevem, de onde escrevem, quando escrevem, para quem escrevem e porque escrevem.

Nas publicações selecionadas é possível observar regularidades de referentes discursivos em torno da luta pela qualidade da educação, tais como: os direitos humanos; o direito à educação de qualidade; as políticas públicas e sociais de EJA; o reconhecimento social; a relação com o saber; o diálogo. Para todos esses referentes os pesquisadores se apoiam em princípios legais ou teóricos reconhecidos na academia.

Em relação à coexistência com outros enunciados, mencionaremos apenas os cinco teóricos mais citados e amplamente reconhecidos, e dois exemplos que consideramos clássicos para esse requisito. Tal opção deve-se ao fato de que nos estendermos nessa condição fugiria aos propósitos do ensaio. No entanto, precisamos mostrar que os conteúdos das publicações atendem a essa condição necessária a um lugar de enunciação, isto é, para que a permanência escolar possa ser também percebida como um lugar de observar, agir e dizer sobre o direito à qualidade na educação para jovens e adultos dos meios populares:

1 - Os cinco teóricos mais referidos em suas mais diversas produções foram: os brasileiros Paulo Freire e Sérgio Haddad; e os franceses Bernard Charlot, Bernard Lahire e Pierre Bourdieu.

2- Oliveira e Araújo (2005, p. 21), no artigo intitulado Qualidade do ensino: uma nova dimensão da luta pelo direito à educação, são emblemáticos sobre a posição enunciativa do pesquisador brasileiro da área de educação e, especialmente, daqueles interessados na permanência escolar, conforme trecho a seguir:

Cabe, pois, criar as condições de efetivação do princípio constitucional do padrão de qualidade do ensino (art. 206, inciso VII da Constituição Federal) como nova dimensão do direito à educação. $\mathrm{O}$ reconhecimento dessa necessidade não nos exime, pesquisadores da área de educação, do desafio e da responsabilidade de traduzir o "padrão de qualidade" num conjunto de indicadores passível de exigência judicial.

3 - Pereira (2001, p. 114), pesquisador da Universidade de Brasília (UnB), que investigou o PROEJA no IF Goiás — campus Goiânia, apresenta-nos, num dos raros diálogos entre as publicações selecionadas, citando Claudia Klinski (2009), da UFRGS, uma passagem de Paulo Freire que nos parece ser, ao mesmo tempo, o maior motivo de indignação e o maior incentivo para continuar avançando nas pesquisas sobre a permanência escolar:

Tal como percebido no estudo de Klinski (2009), o acolhimento dos jovens e adultos do Campus pesquisado foi fundamental para sua motivação. Ao discutir a situação existencial dos oprimidos, Freire (2005) cita a autodesvalia, como um comportamento de assimilação da ideia de sua inferioridade diante dos opressores. "De tanto ouvirem de si mesmos que são incapazes, que não sabem nada, que não podem saber, que são enfermos, indolentes, que não produzem em virtude de tudo isso, terminam por se convencer de sua incapacidade".

Tal situação demanda da instituição escolar, práticas pedagógicas e administrativas, pelas 
quais os estudantes se sintam acolhidos e capazes de se perceberem como sujeitos ativos, de direito, de tal modo que ao longo de sua permanência, “os oprimidos [...] precisam reconhecer-se como homens, na sua vocação ontológica e histórica de ser mais".

Essas são algumas formas de escrever sobre permanência escolar nas quais se observa um esforço de argumentar na direção contrária às formas de escrever instituídas sobre evasão escolar, de modo a conquistar espaço para fazer valer o direito à educação de qualidade. Entende-se, por isso, que estes são exemplos de que permanência escolar configura um domínio em que há coexistência para outros grupos de enunciados, preenchendo, assim, a condição do terceiro requisito para se perceber permanência escolar como um lugar de enunciação em favor da qualidade na educação.

Quarto requisito, uma materialidade: ter possibilidades de usos ou de reutilização

O último requisito para se pensar permanência escolar como um lugar de se observar, agir e dizer sobre o direito à qualidade na educação, diz respeito à possibilidade de multiplicação das experiências que deram certo - ou observações e debates em andamento - em termos de aumento da permanência escolar nas instituições escolares pesquisadas pelos autores das publicações selecionadas.

Quanto ao universo da didática em sala de aula, selecionamos três exemplos representativos de três práticas: o incentivo à autoestima, o incentivo ao diálogo e o incentivo ao "dessilenciamento", nos quais grifamos em negrito os trechos centrais:

1- Santos (2007, p. 13), numa turma de alfabetização de EJA de um bairro de Brasília, afirma que o trabalho para permanência escolar se compõe de "Ações simples que desafiam os dados estatísticos sobre a EJA e a evasão no DF [...]", tais como:

- ter paciência durante os diálogos professor x aluno;

- o trabalho feito para elevar a autoestima dos sujeitos que são aprendizes e ensinantes (muitos não percebem que também ensinam);

- a professora estimula o sonho, faz com que o educando acredite ser capaz.

2- Santos (2007, p. 147), em outro momento de sua investigação, apresenta-nos a noção de “dessilenciamento" como uma espécie de técnica apresentada por seu professor de mestrado Renato Hilário Reis, que passa a observar na sala de aula onde pesquisa:

[...] No rompimento com o silenciamento as vozes dos educandos vão deixando escapar que há um novo sistema formador sendo instaurado dentro da sala de aula

[...] Nesse encontro de vozes Paulo passa pelo ritual do dessilenciamento. É sujeito de saber e concomitante sujeito de poder.

[...] E vem o processo de dessilenciamento que é fator essencial para a permanência aluno falante é aluno pensante, necessariamente, se houver mediação estratégica para o falar e o pensar.

3- Rute Favero (2006, p. 6) ${ }^{19}$ analisa recursos que permitiam interações entre os atores do processo, enfocando "[...] cinco categorias que permitissem identificar a ocorrência de diálogo: cooperação, incentivo, equidade na relação, participação contínua e geração de conhecimento".

Observando os três exemplos acima, vemos que o primeiro traz à tona a questão da baixa autoestima, que remete à "autodesvalia" de Freire, citada anteriormente. Esta prática de atividades

\footnotetext{
${ }^{19}$ Embora o trabalho de Rute Favero trate da permanência na Educação a Distância, a citamos aqui porque entendemos que as cinco categorias que utilizou para identificar a presença do diálogo nas interações digitais podem contribuir para as reflexões sobre as interações presenciais, face à importância do diálogo para fomentar a permanência em qualquer instância de ensino.
} 
que estimula a autopercepção positiva dos alunos surge também em outros trabalhos (Matias, 2003; Mileto, 2009; Silva, 2010; Carmo et al., 2012) sem se confundir com o modismo das "técnicas de autoajuda".

Nos outros dois exemplos, é possível inferir que a elevação da autoestima na segunda e terceira pesquisas se dá pelo estímulo ao diálogo e ao "soltar a voz" dos alunos, como vimos na citação de Rute Favero (2006) e de Santos (2007), que apresenta o neologismo "dessilenciamento" como técnica de "fazer falar", o qual nos remete à indagação de Boanventura de Souza Santos (2001, p. 19): "Como fazer falar o silêncio sem que ele fale necessariamente a linguagem hegemônica que o pretende fazer falar?". Nesse sentido, é fundamental lembrar a centralidade do diálogo nas lições de Paulo Freire. Provavelmente tais propostas são desdobramentos do diálogo, esse "recurso didático", que invariavelmente "dá certo" nas turmas de jovens e adultos dos meios populares.

Os dois exemplos seguintes vão enfatizar a boa qualidade de ensino vinculada à qualidade do trabalho docente, ao bom profissional. Embora esses não sejam exemplos de práticas multiplicadoras, envolvem a questão da formação do professor e, portanto, da universidade onde tais professores se formam. Nesse sentido, infere-se que o que há de se multiplicar é a crítica aos modelos de formação na universidade pública (assim a denominamos porque o foco é a qualidade da educação pública), especialmente nas licenciaturas de qualquer área.

1 - Steimbach (2012, p. 95), que estudou um Curso Técnico em Agropecuária Integrado do Paraná, afirma que “[...] os bons profissionais e a boa qualidade de ensino foram os únicos elementos citados como ponto positivo em todos os segmentos pesquisados".

2 - Pereira (2011, p. 126) pesquisou os cursos Técnicos Integrados em Cozinha e Serviços de Alimentação do Proeja do IF Goiás — campus Goiânia, e registrou que os fatores de permanência apontados foram: "[...] a qualidade do trabalho docente, o acolhimento, a qualidade da estrutura da instituição e do serviço de assistência ao estudante". Entretanto, "[...] pelo que se verifica nas entrevistas, o 'calcanhar de Aquiles' da permanência do aluno talvez esteja na qualidade do trabalho docente com esse público”.

A analogia com o "calcanhar de Aquiles", no segundo exemplo, parece-nos emblemática. Significa que se houver qualidade do trabalho, as outras variáveis que envolvem a permanência tornam-se secundárias e vice-versa. Nesse sentido cabe perguntar: o que significa qualidade no trabalho docente? Qualidade no ponto de vista de quem? Quais são as características do professor que os alunos jovens e adultos julgam ser de qualidade? Estas são indagações que não observamos entre as publicações selecionadas.

Em relação à instituição escolar como um todo — de qualquer nível de escolaridade — percebese que várias publicações se dedicam a dar visibilidade às conquistas normativas alcançadas. Outras sugerem normas em suas instituições num esforço para tomar a Constituição e a LDBEN n. 9394/96 como referência para garantir o direito à permanência escolar. Exemplificamos uma delas pelo seu teor instituinte de normatização.

Noro (2011, p. 72), cuja pesquisa teve o objetivo de analisar as diferentes práticas de gestão pedagógica e de relações sociais utilizadas por alunos, professores e gestores que têm contribuído para o acesso e a permanência no PROEJA, no Curso Técnico em Administração, campus Sapucaia do Sul, apresenta as iniciativas do IFSUL na direção da normatização de políticas de permanência no interior da instituição:

A partir do decreto 7.234 de 19 de julho de 2010, que dispõe sobre o Programa Nacional de Assistência Estudantil (PNAES) — o IFSUL implementou uma política de permanência para seus estudantes em todos os níveis, através da criação, em 2011, de uma diretoria específica, a Diretoria de Gestão de Assistência Estudantil (DIGAE), órgão sistêmico responsável por 
orientar, assessorar e acompanhar projetos e atividades relacionadas à assistência estudantil, considerando as especificidades dos campi do IFSUL. Suas competências compreendem: propor as políticas relativas à prestação da assistência estudantil do IFSUL; promover ações para o inter-relacionamento dos integrantes da comunidade estudantil atuando como agentes da política social, cultural e comunitária, orientar, assessorar e acompanhar os programas e projetos de prestação de assistência social e estimular a organização de entidades estudantis.

Em continuidade, Noro (2011) informa que o DIGAE, em 02 de junho de 2011, editou o Regulamento da Política de Assistência Estudantil do IFSUL, no qual, no segundo artigo, destaca o seu terceiro princípio: "[...] a busca pela igualdade de condições para o acesso, a permanência e o êxito dos estudantes". Ainda em agosto de 2011, a diretoria instituiu a Câmara de Assistência Estudantil de caráter consultivo e propositivo, com a finalidade de contribuir para a integração dos campi, devendo atuar na defesa da Assistência Estudantil, visando, entre outros aspectos, contribuir para a permanência e o êxito dos estudantes do IFSUL.

Noro (2011) conclui que as políticas de assistência estudantil, formação de professores e de qualificada infraestrutura nas escolas são fundamentais na garantia da permanência dos estudantes, e que as relações familiares e de amizade também determinam o sucesso escolar.

Entendemos que tais exemplos, entre outros presentes nas publicações selecionadas, são emblemáticos quanto aos lugares de fazer a permanência escolar acontecer, servindo de referência - como narrativas de caminhos já trilhados — para possível multiplicação.

\section{Um ponto de parada nos percursos}

Considerando que esse ensaio se constrói sob ritmo de um exercicio da paciência do conceito, nesse momento, entendemos ser necessário delimitar um ponto de parada, como um lugar para se perguntar e refletir sobre como esses percursos se encontram, como se relacionam entre si, como se relacionam em tensão com o discurso estabelecido da evasão, e se conservam coerentes com as pistas iniciais que nos apontaram caminhos.

Um ponto de parada e de perguntas para que se possa perceber como a experiência instituinte de escrever sobre permanência escolar vai-se configurando a partir de um "estado de coisas" no qual é preciso lançar reflexões de visibilidade e de compreensão mínimas para ser possível delimitar e expressar tanto nossas dúvidas quanto nossas expectativas em relação ao desenvolvimento de uma opção analítica que tem como objeto a permanência escolar.

A partir do problema proposto neste ensaio - por que tão poucos estudos sobre a permanência em relação à extensa produção de trabalhos sobre a evasão escolar? - delimitamos o terreno da pesquisa no campo da educação de jovens e adultos. Neste terreno foi possível traçar o longo caminho já percorrido pelas pesquisas sobre evasão e fracasso escolar, cujos resultados, em maioria apontam para a responsabilização do aluno ou da família, seja por motivos de trabalho, de cansaço, de desinteresse, de falta de conhecimentos básicos. E, mesmo que a LDBEN n. 9394/96 tenha instituído o princípio da igualdade de "acesso e permanência", sem qualquer menção ao vocábulo evasão, só após 2007 surge um número maior de pesquisas sobre permanência escolar.

Entre as cinco "pistas" arroladas neste ensaio (p. 5 e 6) para explicar o aumento das publicações sobre permanência escolar, a que nos parece mais plausível, historicamente falando, como "fio da meada" que se desenrola com o auxílio de causas complementares, é a que menciona a saturação dos modelos téoricos e metodológicos das pesquisas sobre evasão escolar. 
Entendemos que esta seja a "pista" que explica o fato de várias pesquisas usarem permanência escolar como símbolo de mudança na forma de pesquisar sobre jovens e adultos dos meios populares, tendo por isso se configurado no primeiro percurso de categoriz̧ação dos relatos presentes nas publicações selecionadas.

Intuímos que essa saturação das explicações, presentes em muitas pesquisas que tratam da evasão escolar, ocorreu porque construíram abordagens insistentes e inconsequentes, humanisticamente falando, em relação a jovens e adultos que retornam à escola. Tais abordagens se acumularam historicamente, enquanto a universalização do acesso à escola era o primeiro objeto de luta pela democratização do ensino no país. As abordagens podem ser observadas em duas direções convergentes: a da responsabilização individual pelas razões de saída da escola; e a da recusa em explicitar a responsabilização coletiva dos operadores da educação, desde o micromundo da escola, passando pelas secretarias de educação, até instituições universitárias ou de educação profissional que possuem interface com a educação de jovens e adultos.

Por isso, consideramos que as perspectivas das poucas dezenas de publicações sobre permanência, que explicitam uma ruptura simbólica em relação às abordagens das várias centenas de publicações sobre evasão escolar, configuram um ponto de inflexão que exige visibilidade, tamanha a urgência de se encontrar "caminhos mentais coletivos" na direção de uma educação de qualidade no país. Aqui entendemos tal ponto de inflexão como uma bifurcação. Para Prigogine $(2000)^{20}$ as bifurcações aparecem "em pontos especiais nos quais a trajetória seguida por um sistema se subdivide em ramos". Todos os ramos são possíveis, mas só um deles será seguido. No geral, não se vê apenas uma bifurcação. Elas tendem a surgir em sucessão. No plano da sociedade, as bifurcações são a um só tempo um sinal de instabilidade e um sinal de vitalidade, tendo em vista que nas recentes ciências da complexidade há uma negação do determinismo, em favor de uma afirmação da criatividade em todos os níveis da natureza.

Marcada a bifurcação, a partir da saturação das abordagens sobre evasão escolar, as pesquisas sobre permanência escolar mencionadas abrem uma fenda no discurso dominante e instauram uma origem, uma gênese, uma experiência instituinte, que supomos inconsciente pelo caráter dispersivo das pesquisas, constatado nas iniciativas isoladas dos pesquisadores, sem diálogo entre si.

Entretanto, se as pesquisas sobre permanência escolar não dialogam entre si, estas dialogam com o discurso dominante da evasão, necessariamente, em processo de tensão. Afinal, essa é uma característica da experiência instituinte, conforme Linhares (2007).

Por isso, é possível afirmar que o segundo percurso que trata de relatos sobre a permanência escolar como lugar de agir, refletir e escrever sobre o direito à qualidade na educação para jovens e adultos dos meios populares assemelha-se com o histórico percurso dos discursos presentes nas pesquisas sobre a evasão, no que diz respeito ao conceito de enunciação de Foucault (1997, p. 133). Porque tanto um quanto o outro, vale repetir, se apoiam em conjuntos de signos que requerem para se realizar: um referencial (que não é exatamente um fato, um estado de coisas, nem mesmo um objeto, mas um princípio de diferenciação); um sujeito (não a consciência que fala, não o autor da formulação, mas uma posição que pode ser ocupada, sob certas condições, por indivíduos diferentes); um campo associado (que não é o contexto real da formulação, a situação na qual foi articulada, mas um domínio de coexistência para outros enunciados); uma materialidade (que não é apenas a substância ou o suporte da articulação, mas um status, regras de transcrição, possibilidades de uso ou de reutilização).

\footnotetext{
${ }^{20}$ IIya Prigogine (1917-2003), cientista de origem russa, viveu na Bélgica desde os 12 anos. Em 1977, recebeu o Prêmio Nobel de Química. É autor de O fim das certezas (Ed. Unesp) e A Nova Aliança (Ed. UnB), entre outros. A noção de bifurcação e de flutuação aplicada às Ciências Sociais se difundiram no Brasil após a publicação de Carta às Gerações Futuras no “O Estado de S Paulo”, Caderno Mais! em 30 jan. 2000.
} 
Portanto, se os dois discursos atendem aos requisitos da função enunciativa de Foucault, será na diferença entre os dois enunciados que deveremos nos pautar para prosseguir. Isto porque os enunciados, pelos requisitos que lhes são impostos, só são possíveis pelo imperativo histórico. Isto é, os enunciados sobre permanência escolar, mesmo dispersos, não se dão por acaso ou por uma inspiração atemporal.

Será, portanto, a categorização discursiva em torno da permanência como símbolo de ruptura com a evasão que lhe vai dar caráter de experiência instituinte, porque a responsabilização pela permanência de jovens e adultos na escola só é possível se assumida coletivamente pelos operadores educacionais. Mesmo que esta coletividade esteja restrita ao conjunto dos alunos e do professor, ela estará ocupada em busca de meios para esses alunos se sentirem solidários no processo de aprendizagem, porque pertencem e "estão no mesmo barco", como aponta Mileto (2009).

Essa é a relação fundamental entre as duas categorizações. Isto é, por um lado assemelham- se como enunciados, mas por outro o discurso instituinte de escrever sobre permanência recusa e resiste ao discurso estabelecido da evasão.

Pelos depoimentos e análises postos pelos pesquisadores, pode-se dizer, apoiados em Reis (2009a), que a permanência simbólica e a permanência material complementam-se nessa resistência e nesse persistir em torno de uma construção coletiva em direção à garantia e à proteção do direito à qualidade da educação. Direito esse que, necessariamente, passa pela implantação de micro e macro políticas de reconhecimento social e pertencimento desses sujeitos nas instituições que buscam, ao retornar à escola.

Vale ressaltar que compreendemos serem estas reflexões muito mais próximas do princípio constitucional da "igualdade de acesso e permanência na escola", do que aquelas reflexões que responsabilizam individualmente jovens e adultos por abandonarem a escola. Isso pela mudança epistemológica no objeto de investigação da EJA — de "o que faz o aluno sair" para "o que faz o aluno ficar" na escola. Mudança aparentemente simples, para a qual sugerimos o pensamento impensado de Bourdieu para nomeá-la de flutuação, outro termo cunhado por Prigogine (2000). Isto porque Prigogine afirma que, em períodos de transição histórica, configuradas pelas bifurcações insurgentes, as flutuações $^{21}$ podem ser decisivas.

O que Prigogine afirma é que em proximidade com a instabilidade, as flutuações desempenham papel fundamental. E, em geral, apesar das bifurcações poderem seguir por várias direções, são as flutuações os elementos "estranhos" que determinam o que há de prevalecer nos períodos de instabilidade. E, nesse sentido, as ações individuais ou de pequenos grupos, que em momentos de estabilidade não têm visibilidade, em momentos de instabilidade, ao contrário, podem adquiri-la. São essas flutuações que apontam para o vigor criativo, que parecem permitir a Mileto (2009, p. 116) escrever sobre "infinitas possibilidades que a imaginação criativa pode conceber como novos mundos prenhes de utopias possíveis", porque se pode constatar que, nesse sentido, a luta pela EJA como direito à educação também é uma flutuação, assim como a abordagem da permanência, em detrimento da "evasão".

Se tomarmos a afirmação de Mileto como ponto de referência e fizermos um caminho inverso nesses processos de bifurcações, encontraremos uma determinante flutuação na ramificação que foi o processo de massificação da escola pública a partir da década de 1990, que significou a

\footnotetext{
${ }^{21}$ Flutuação é outra noção nuclear para Prigogine. Exemplificando, o autor diz que há quarenta anos o número de cientistas interessados na física de estado sólido e na tecnologia da informação não passava de umas poucas centenas. Era uma flutuação, quando comparado às ciências como um todo. Hoje, essas disciplinas se tornaram tão importantes que têm consequências decisivas para a história da humanidade.
} 
superação das barreiras que antes impediam as camadas populares de a frequentarem ${ }^{22}$. Superação, porém, marcada pelo contexto de uma sociedade desigual, com altos índices de pobreza e violência, que vão trazer para o interior da escola conflitos e contradições de uma estrutura social excludente, interferindo nas trajetórias escolares e colocando novos desafios à escola (Sposito, 2005), em especial àquelas que ofertam a modalidade de Educação de Jovens e Adultos, integradas ou não à educação profissional.

Nesse sentido, a partir da ruptura vivida pelos poucos pesquisadores em relação ao discurso da evasão escolar, é que aventamos uma expectativa acadêmica quanto à expansão das pesquisas sobre permanência escolar nos próximos anos.

\section{Sobre o que fizemos e sobre uma ideia possível de se fazer}

Os objetivos para verificar se essa mudança pode ser anunciada foram: a) categorizar as formas de abordar o termo permanência escolar, relacionadas direta ou indiretamente com a EJA, presentes em 31 publicações, no período entre 1998 a 2012; e b) apontar que as abordagens dos pesquisadores podem ser consideradas como uma gênese de construção coletiva, mesmo que ainda em formação dispersa, tendo em vista que, como inferimos, escolhem o objeto permanência escolar pelo fato de o tornarem um lugar de experiência instituinte para agir, refletir e escrever sob o princípio do direito à qualidade da educação.

Para atingir os objetivos, nos utilizamos da noção de percurso por meio de relatos, a partir de uma realidade na qual as publicações encontram-se rarefeitas, pois não há referências teóricas suficientemente estabelecidas a respeito. Por isso, uma alternativa possível seria delinear trajetórias dos pesquisadores em torno da permanência escolar e, com isso, perceber em quais pontos fazem interseção. Entendemos que estes pontos são essenciais para aqueles que queiram se orientar em direção à permanência escolar como elemento intrinsecamente ligado à educação de qualidade.

Usamos a metáfora do lugar — na verdade, lugares mentais — para percorrermos a temática da permanência escolar como objeto de pesquisa nas publicações selecionadas. Julgamos que essa foi uma boa escolha metodológica para um primeiro diálogo com as pesquisas, como nos propusemos a fazer a partir deste ensaio.

Entendemos que conseguimos transitar pelos diversos caminhos realizados pelos pesquisadores, observando-lhes tanto os recortes de investigação quanto os objetivos, metodologias e perspectivas teóricas adotadas em torno do objeto permanência escolar, a partir do universo escrito disponível nas 31 publicações.

Sob tal orientação metodológica para percorrer as publicações selecionadas, foi possível nos apropriarmos de noções teóricas de Foucault (1997) e de Orlandi (2005), que também se referem à questão do lugar. Com o objetivo de organizar as proposições e abordagens dos autores em categorias, pudemos fazê-lo de maneira a dar-lhes visibilidade não só em uma (ou mais) das categorias propostas, mas também na direção de vê-las como experiências instituintes de escrita sobre permanência escolar.

Foram duas as categorias criadas para dialogar com as publicações selecionadas, percebendoas como experiências instituintes:

- A permanência escolar como símbolo de mudança na forma de pesquisar sobre jovens e adultos dos meios populares; e

\footnotetext{
${ }^{22}$ Informação com base na nota de rodapé n. 5 do artigo de Dayrell, (2007, p. 1116) que reproduzimos: "Segundo dados do IBGE, PNAD (2001), entre 1995 e 2001, por exemplo, o número total de estudantes entre 15 e 24 anos passou de 11,7 para 16,2 milhões. Neste mesmo período, o ensino médio registrou um aumento de 3 milhões de matrículas, significando um crescimento relativo de 65,1\%".
} 
- A permanência escolar como lugar de agir, refletir e escrever sobre o direito à qualidade na educação para jovens e adultos dos meios populares.

Foi, portanto, a partir da criação dessas categorias, que discutimos se as escritas dos pesquisadores das publicações selecionadas configuram uma experiência instituinte sobre permanência escolar, anunciando mudanças por meio de uma nova opção analítica sobre movimentos de saídas e retornos à escola de jovens e adultos.

Se as formas de escrever sobre permanência atendem os requisitos da enunciação e se tais formas explicitam uma ruptura simbólica e material, considerando que estão dispersas e rarefeitas, podemos dizer que atingimos o objetivo de apontar para uma gênese de construção coletiva do termo permanência escolar.

Entretanto, é preciso manter o princípio da dúvida, principalmente, porque estamos comprometidos com o exercício da paciência do conceito de permanência que nos impõe um trabalho contínuo de criação de estratégias para resistir e persistir aos apelos do discurso estabelecido. Dessa forma, é preciso manter as duas indagações que foram orientando a organização do nosso ensaio, na medida em que escrevíamos:

1- Poderiam as experiências de escrever sobre permanência escolar presentes nas publicações selecionadas serem consideradas como gênese de uma formação discursiva sobre permanência e scolar?

2- Tais experiências instituintes de escrita dariam sentido à permanência escolar como uma função enunciativa, como lugar de enunciação de onde quem fala pode dizer também para além das medidas de fluxos escolares, sobre reflexões e práticas do direito à educação de qualidade?

Imaginamos que tais perguntas podem se transformar em um convite, a todos os pesquisadores com os quais dialogamos sobre permanência escolar, para prosseguir na construção coletiva desse conceito. Seriam oportunas contribuições conceituais e metodológicas desses pesquisadores-autores reafirmando o conceito de permanência escolar e, quem sabe, revertendo a tendência dominante da concepção de evasão escolar.

\section{Referências}

Amaral, D. K. (2010). História de (re)provação escolar: vinte e cinco anos depois. Dissertação (Mestrado em Educação) - Univesidade de São Paulo, São Paulo, Faculdade de Educação, São Paulo, SP.

Amarante, A. A.; Noro, M. M. C. \& Oliveira, L. T. B. (2009). Processo de ingresso e permanência: estudos das relações possíveis na implantação do PROEJA, na Unidade Sapucaia do sul do CEFET/RS. In: XII Congresso da associação Internacional para pesquisa Cultural - ARIC, Anais... Florianópolis, SC, Brasil.

Aulete, F. J. C. (2011). Novíssimo Dicionário contemporâneo da língua portuguesa Caldas Aulete.Rio de Janeiro: Lexikon.

Azevedo, F. F. dos S. (2010). Dicionário Analógico da Lingua Portuguesa: ideias afins/thesaurus. 2. ed. Rio de Janeiro: Lexicon.

Bobbio, N. (2004). A Era dos Direitos. Rio de Janeiro, Editora Campus. Bourdieu, P. (1988). Lições de Aula. São Paulo: Ed. Ática.

Bourdieu, P. (1998). O poder simbólico. 2 ed. Rio de Janeiro: Bertrand Brasil.

Bragança, G. A. (2008). A produção do saber nas pesquisas sobre o fracasso escolar (1996-2007). Dissertação (Mestrado em Educação) - Programa de Pós-Graduação em Educação, Universidade do Estado do Rio de Janeiro, Rio de Janeiro, RJ. 
Bragança, I. F.S. (2003). Memórias e práticas instituintes na escola. In: $26^{a}$ reunião da ANPED. Disponível em: <http://www.anped.org.br/reuniões/26/posteres/inesferreirabragança.rtf>. Acesso em: 05 out. 2012.

Brasil. (1996). Ministério da Educação. Lei de Diretrizes e Bases da Educação Nacional (Lei 9394/96). Brasília.

Brasil. (1988). Constituição da República Federativa do Brasil de 1988. Brasília. Disponível em: <http://www.planalto.gov.br/civil_03/constituicao/constitui\%C3\%A7ao.htm>. Acesso em: 22 mar. 2004.

Cardoso, J., Ferreira, M. J. R. F. (2012). Inclusão e exclusão: o retorno e a permanência dos alunos na EJA. Debates em Educação Científica e Tecnológica, v. 02, nº. 2, p. 61 a 76.

Carmo, G. T. (2010). O enigma da Educação de Jovens e Adultos: um estudo das evasões e retorno à escola sob a perspectiva da teoria do reconhecimento social. Tese (Doutorado em Sociologia Política) - Programa de Pós-Graduação em Sociologia Política, Universidade Estadual Norte Fluminense Darcy Ribeiro, Campos dos Goytacazes, RJ.

Carmo, G. T. \& Moura, S. A. (2012). Poder e subjetividades nos atos de escrever sobre o PROEJA. Campos dos Goytacazes, RJ: EdUENF.

Carmo, G. T.; Bulhões, R. B. C.; Soares, T. S. \& Ferreira, L. R. (2012). Alunos Jovens e Adultos de Itaperuna: quem mais contribui para que permaneçam na escola. IV Mostra de Extensão IFFUENF-UFF, CD da IV Mostra de Extensão IFF-UENF-UFF, Campos dos Goytacazes, RJ.

Certeau, M. (1998). A invenção do cotidiano (2nd ed.). Petrópolis: Vozes.

Correia, C. S. V.; Heidrich, E. M. C. \& Rateke, F. G. (2007). A Permanência do Sujeito na EJA: a condição de grupo e a afetividade no cotidiano escolar. Monografia (Curso de Especialização em Educação Profissional e Educação de Jovens e Adultos) - Centro Federal de Educação Tecnológica de Santa Catarina, Florianópolis, SC.

Coura, I. G. M. (2007). A terceira Idade na Educação de Jovens e Adultos: expectativas e motivações. Dissertação (Mestrado em Educação) - Universidade Federal de Minas Gerais, Faculdade de Educação, Belo Horizonte, MG.

Cruz, N. C. (2011). Casos pouco prováveis: trajetórias ininterruptas de estudantes da EJA no ensino fundamental. Dissertação (Mestrado em Educação) - Faculdade de Educação, Universidade Federal de Minas Gerais, Belo Horizonte, MG.

Dantas, A. C. L. (2009). Fóruns de EJA: mobilização na luta pelo direito à educação de Jovens e Adultos. In: Cadernos de Atividades e Resumos do $17^{\circ}$ COLE - Congresso de Leitura do Brasil, Campinas-SP.

Dantas, D. C. L.; Martins, L. A. R. (2007). A permanência de jovens e adultos com deficiência mental na escola regular: a concepção das mães acerca dos limites e possibilidades vivenciados pelos filhos.Londrina, PR: IV Congresso Brasileiro Multidisciplinar de Educação Especial.

Dayrell. J. (2007). A escola "faz" as juventudes? Reflexões em torno da socialização juvenil. Educação e Sociedade, Campinas, vol. 28, n. 100 - Especial, p. 1105-1128.

Dias, A. F. (2011). O jovem autor de ato infracional e a educação escolar: significados, desafios e caminhos para a permanência na escola. Dissertação (Mestrado em Educação) - Programa de Pósgraduação em Educação, Universidade Federal de São Carlos, São Carlos, SP.

Dominick, R. dos S. \& Cruz, L. (2013). Considerações acerca da conservação e da transformação para o Aleph: uma análise do instituinte na educação. Aleph (UFF. Online), Ano VIII, n. 20, p. 1-6.

Ens, R. T.; Ribas, M. S. (2012). Políticas educacionais e o acesso e permanência na Educação de Jovens e Adultos. IX Anped Sul Seminário de Pesquisa em Educação da Região Sul, Caxias do Sul, RS.

Favero, R. V. M. (2006). Dialogar ou evadir: eis a questão! Um estudo sobre a permanência e a evasão na Educação a Distância. Dissertação (Mestrado em Educação) - Universidade Federal do Rio Grande do Sul, Porto Alegre, RS. 
Ferreira, A. B. H. (2009). Novo Dicionário Aurélio da Lingua Portuguesa (4. ed.). Curitiba: Positivo. Foucault, M. (1997). A arqueologia do saber (5. ed.). Rio de Janeiro: Forense Universitária.

Freire, P. (2003). Educaşão como prática da liberdade (27th ed.). Rio de Janeiro: Paz e Terra.

Gallo, S. (2009). Filosofia da Educação no Brasil do século XX: da crítica ao conceito. EccoS Revista cientifica, ano 1, 9 (2), p. 261-284.

Ginzburg, C. (2002). Mitos, Emblemas, Sinais. São Paulo: Cia. das Letras.

Gusmão, J. B. B. (2010). Qualidade da Educação no Brasil: consenso e diversidade de sentidos. Dissertação (Mestrado em Educação) - Universidade de São Paulo, São Paulo, SP.

Haddad, S. (1987). Ensino Supletivo no Brasil: o estado da arte. REDUC/INEP, Brasília, DF.

Haddad, S. (2000). O Estado da Arte das Pesquisas em Educação de Jovens e Adultos no Brasil: A produção discente da pós-graduação em educação no período 1986 - 1998. Ação Educativa, São Paulo, SP.

Honneth, A. (2003). Luta por reconbecimento: a gramática moral dos conflitos sociais. São Paulo: Ed. 34.

Klinski, C. S. (2009). Ingresso e permanência de alunos com ensino médio completo do Instituto Federal Sul-RioGrandense: Campus Charqueadas. Dissertação (Mestrado) - Faculdade de Educação, Universidade Federal do Rio Grande do Sul, Porto Alegre, RS.

Lacotiz, A. (2006). Análise do sufixo ança/-ença/-ância/-ência na obra do simbolista João da Cruz e Souza. Estudos Linguísticos, 35, p. 320-329.

Larrosa Bondia, J. (2002). Notas sobre a Experiência e o Saber de Experiência. Revista Brasileira de Educação, 19.

Lenskij, T. (2006). Direito à permanência na escola: a lei, as políticas públicas e as práticas escolares.

Dissertação (Mestrado) - Universidade Federal do Rio Grande Sul, Faculdade de Educação, programa de Pós-Graduação em Educação, Porto Alegre, RS.

Linhares, C. (2007). Experiências instituintes na educação pública? Alguns porquês dessa busca. Revista de Educação Pública, 6 (31), p. 139-160.

Martins, A. P. (2006). A escola, a ruptura, o retorno: a Educação de Jovens e Adultos. Dissertação (Mestrado) - Centro de Ciências da Educação, Universidade Regional de Blumenau, Blumenau, SC.

Matias, I. S. (2003). Centro Federal de Educação Tecnológica do Amažonas: Uma reflexão sobre as condições de ingresso, permanência e evasão. Dissertação (Mestrado) - Programa de Pós- graduação em Educação na área de Educação e Trabalho, Centro de Ciências da Educação, Universidade Federal de Santa Catarina, Florianópolis, SC.

Melucci, A. (2001). A Invenção do Presente - movimentos sociais nas sociedades complexas. Petrópolis - RJ: Vozes.

Mesquita, L. F. (2011). Acesso, permanência e sucesso escolar. In: II Fórum FGE Instituto Federal de Educação, Ciência e Tecnologia do Triângulo Mineiro - IFTM, Anais... Uberlândia, MG. Disponível em: <http://www.iftm.edu.br/proreitorias/ensino/PDF/eventos/permanencia_e_sucesso_esco lar.pdf>. Acesso em: 05 out. 2012.

Mileto, L. F. M. (2009). No mesmo barco, dando força, um ajuda o outro a não desistir: Estratégias e trajetórias de permanência na Educação de Jovens e Adultos. Dissertação (Mestrado em Educação) Faculdade de Educação da Universidade Federal Fluminense, Niterói, RJ.

Mileto, L. F. M. \& Carmo, G. T. (2010). Propostas de conversão do olhar sobre a EJA: pesquisando o "enigma" da permanência. $1^{\circ}$ SEEJA - Seminário de Educação de Jovens e Adultos, PUC Rio, Rio de Janeiro/RJ.

Moraes, M. S. \& Becker, F. (2010). Aprendizagem significativa e permanência na escola. In: Benvenuti, J.; Arenhaldt, R. \& Santos, S. V. et. al. (Orgs.). Refletindo sobre PROEJA: Produções de Porto Alegre. Cadernos PROEJA II. Especialização Rio Grande de Sul, 4, Pelotas, RS: Editora Universitária/UFPEL. 
Moura, D. (2006). O PROEJA e a Rede Federal de Educação Profissional e Tecnológica. Natal. (mimeo). Nascimento, L. C. do (2010). Algumas considerações sobre a mudança da percepção e crise da experiência segundo Walter Benjamin. Campinas, SP: Cadernos da Graduação, 8, p. 206-2013.

Noro, M. M. C. \& Oliveira, L. T. B. (2011). Acesso e permanência do estudante do PROEJA/RS:

percepções, possibilidades, movimentos e práticas. Porto Alegre, RS.

Noro, M. M. C. Gestão de processos pedagógicos no PROEJA.: razão de acesso e permanência. Dissertação (Mestrado em Educação ) Programa de Pós-Graduação em Educação, Faculdade de Educação , Universidade Federal do Rio Grande do Sul, Porto Alegre, RS.

Nunes, J. M. C. P. (2010). Sujeitos da Educação de Jovens e Adultos: produção da permanência no ensino médio regular noturno. Dissertação (Mestrado) - Programa de Pós-Graduação em Educação, Universidade Federal de Santa Catarina, Florianópolis, Santa Catarina.

Oliveira, L. T. B. \& Paludo, C. Formas de Ingresso e Permanência em PROEJA. In: Benvenuti, J.; Arenhaldt, R.; Santos, S. V. \& Marques, T. B. I. (Orgs.). (2010). Refletindo sobre PROEJA: produções de Porto Alegre. Pelotas/RS: Editora Universitária/UFPEL, 2, 117-137.

Oliveira, P. C. S. (2011). Alfabetizandos/as na EJA: as razões da permanência nos estudos. Dissertação (Mestrado em Educação) - Programa de Pós-Graduação em Educação, Faculdade de Educação, Universidade Federal de Minas Gerais, Belo Horizonte, MG.

Oliveira, R. P. \& Araujo, G. C. (2005). Qualidade do ensino: uma nova dimensão da luta pelo direito à educação. Revista Brasileira de Educação, 28, p. 5-24.

Olson, D. R. (1997). O mundo no papel: implicações conceituais e cognitivas da leitura e da escrita. São Paulo: Ática.

Orlandi, E. P. (2005). Análise do discurso: princípios e procedimentos (6th ed.). Campinas, SP: Pontes. Orlandi, E. P. (1996). Interpretação - Autoria, leitura e efeitos do trabalbo simbólico. Petrópolis: Vozes.

Paiva, J. (2005). Educação de Jovens e Adultos: direito, concepções e sentidos. Tese (Doutorado em Educação) - Universidade Federal Fluminense, Faculdade de Educação, Niterói, RJ.

Patto, M. H. S.; Angelucci, C. B.; Kalmus, J. \& Paparelli, R. (2004). O estado da arte da pesquisa sobre o fracasso escolar (1991-2002): um estudo introdutório. Educação e Pesquisa, São Paulo, 30 (1), p. 52-72.

Pereira, J. V. (2011). O PROEJA no Instituto Federal de Goiás - Campus Goiânia: um estudo sobre os fatores de acesso e permanência na escola. Dissertação (Mestrado) - Faculdade de Educação, Universidade de Brasília, Brasília, DF.

Prigogine, I. (2000). Carta para as futuras gerações. São Paulo, SP: Folha de São Paulo, Caderno Mais, p. 4-7. Disponível em: <http://www1.folha.uol.com.br/fsp/mais/fs3001200004.htm>. Acesso em: 23 abr. 2010.

Reis, D. B. (2009a). Para além das cotas: a permanência de estudantes negros no ensino superior como política de ação afirmativa. Tese (Doutorado) - Programa de Pós-Graduação em Educação da Universidade Federal da Bahia, Bahia, BA.

Reis, D. B. (2012). Continuar ou desistir? Reflexões sobre as condições de permanência de estudantes negr@s na UFRB. In: Sampaio, S. M. R. \& Gonçalves, G. (Orgs.). Observatório da Vida Estudantil: Estudos sobre a vida e cultura universitárias. 1ed. Salvador: Edufba, 1, p. 1- 269. 
Reis, D. B. \& Tenorio, R. M. (2009b). Políticas Públicas de Acesso e Permanência da População Negra no Ensino Superior: Um debate em curso. Cadernos ANPAE, 8, p. 1/11.

Reis, E. P. (1998). Processos e Escolhas - estudos de sociologia política. Rio de Janeiro: Contra Capa. Rocha, J. S. \& Haracemiv, S. M. C.(2004) Entre a permanência e o abandono: uma reflexão sob o olhar do jovem e adulto do ensino médio noturno. Programa de Desenvolvimento Educacional, Curitiba, UFPR.

Santos, B. S. (2001). A crítica da razãa indolente - contra o desperdício da Experiência (3rd ed.). São Paulo: Cortez.

Santos, M. A. M. T. (2007). A produção do sucesso na Educação de Jovens e Adultos: o caso de uma escola pública em Brazlândia-DF. Dissertação (Mestrado em Educação) - Faculdade de Educação, Universidade de Brasília, DF.

Saraiva, F. R. S. (2006). Novíssimo Dicionário Latino-Português. 12. Ed. Rio de Janeiro, RJ: Livraria Garnier.

Silva, J. L. (2010). Permanência e desempenho na EJA: um estudo sobre eficácia escolar no Programa de Educação de Jovens e Adultos do Município do Rio de Janeiro. Tese (Doutorado em Educação) - Pontifícia Universidade Católica do Rio de Janeiro, Rio de Janeiro, RJ.

Silva, M. S. \& Gama, Z. J. (2008). Permanência e evasão escolar são também questões de gênero? (Um ensaio à luz da teoria de gênero). InterSciencePlace Revista Científica Internacional, ano 1, 3, p. 1-21.

Silva, R. D. (2009). A permanência prolongada das totalidades iniciais e a aquisição da língua escrita: um olhar para a EJA. Dissertação (Mestrado em Educação) - Programa de Pós-Graduação em Educação, PUC-RS, Porto Alegre, RS.

Souza, J. (2003). A construção social da subcidadania: para uma sociologia política da modernidade periférica. Belo Horizonte: Ed. UFMG; Rio de Janeiro: IUPERJ.

Souza, S. N. (2004). Experiências Instituintes e Democracia. Aleph (UFF. Online), ano I, n. 1. Sposito, M. P. (1993). A ilusão fecunda: a luta por educação nos movimentos populares. São Paulo: Hucitec; Edusp.

Sposito, M. P. (2005). Algumas reflexões e muitas indagações sobre as relações entre juventude e escola no Brasil. Abramo, H.; Branco, P.P.M. (org.). Retratos da juventude brasileira: análises de uma pesquisa nacional. São Paulo: Instituto Cidadania; Fundação Perseu Abramo, p. 87-128.

Steimbach, A. A. (2012). Juventude, escola e trabalbo: razões da permanência e do abandono no curso Técnico em Agropecuária Integrado. Dissertação (Mestrado) - Programa de Pós-graduação em Educação, Universidade Federal do Paraná, Curitiba, PR.

Stoco, H. P. (2010). A educação de jovens e adultos trabalhadores no PROEJA: acesso e permanência no CEFET-BA. Revista Eletrônica Multidisciplinar Pindorama do Instituto Federal de Educação, Ciência e Tecnologia da Babia - IFBA, no 01 - Ano I - www.revistapindorama.ifba.edu.br

Viana, M. J. B. (1998). Longevidade escolar em famílias de camadas populares: algumas condições de possibilidade. Tese (Doutorado em Educação) - Programa de Pós-Graduação em Educação, Universidade Federal de Minas Gerais, Belo Horizonte, MG.

Zago, N. (2006). Do acesso à permanência no ensino superior: percursos de estudantes universitários de camadas populares. Revista Brasileira de Educação, 11 (32), p. 226-237. 


\section{Apêndices}

Apêndice 1 - Quadro de identificação das 31 publicações selecionadas

Legenda: A - artigo; D - dissertação; T- tese

\begin{tabular}{|l|l|l|}
\hline No & Código & Primeiro autor para identificação nas referências \\
\hline 1 & A1 & Dantas, Dulcinea de Carvalho Lopes. \\
\hline 2 & A2 & Silva, Marinete Santos. \\
\hline 3 & A3 & Mileto, Luís Fernando Monteiro. \\
\hline 4 & A4 & Ens, Romilda Teodora. \\
\hline 5 & A5 & Stoco, Heloisa Pancieri. \\
\hline 6 & A6 & Rocha, Jacqueline Silvério. \\
\hline 7 & A7 & Carmo, Gerson Tavares. \\
\hline 8 & A8 & Amarante, A.A. \\
\hline 9 & A9 & Moraes, Marli Silva. \\
\hline 10 & A10 & Noro, Margarete M. C. \\
\hline 11 & A11 & Oliveira, Luzia. T. B. \\
\hline 12 & A12 & Correia, C.S.V. \\
\hline 13 & A13 & Mesquita, Luiz Fábio. \\
\hline 14 & A14 & Cardoso, Jaqueline Ferreira \\
\hline 15 & D1 & Silva, Raquel Duro. \\
\hline 16 & D2 & Lenskij, Tatiana. \\
\hline 17 & D3 & Klinski, Claudia Dos Santos. \\
\hline 18 & D4 & Noro, Margarete Maria Chiapinotto. \\
\hline 19 & D5 & Oliveira, Paula Cristina Silva. \\
\hline 20 & D6 & Matias, Irlene Dos Santos. \\
\hline 21 & D7 & Nunes, José Manoel Cruz Pereira. \\
\hline 22 & D8 & Steimbach, Allan Andrei. \\
\hline 23 & D9 & Mileto, Luís Fernando Monteiro. \\
\hline 24 & D10 & Santos, Maria Aparecida Monte Tabor. \\
\hline 25 & D11 & Pereira, Josué Vidal. \\
\hline 26 & D12 & Cruz, Neilton Castro. \\
\hline 27 & D13 & Dias, Aline Fávero. \\
\hline 28 & D14 & Martins, Ana Paula. \\
\hline 30 & & Carmor Gerson Tavares. \\
\hline
\end{tabular}


Apêndice 2- Quadros de classificação das publicações selecionadas

\begin{tabular}{|c|c|c|c|c|}
\hline AREA & DISSERTAÇÃO & TESE & REVISTA- ANAIS & TOTAL \\
\hline Educação & $\begin{array}{l}\text { D1-D2-D3-D4-D5- } \\
\text { D6-D7-D8-D9-D10- } \\
\text { D11- D12-D13- D14 }\end{array}$ & T2- T3 & $\begin{array}{l}\text { A1-A3-A4-A5-A6-A7-A8- A9- } \\
\text { A10-A11-A12-A13-A14 }\end{array}$ & 29 \\
\hline Sociologia & & T1 & A2 & 2 \\
\hline
\end{tabular}

\begin{tabular}{|l|l|l|l|l|}
\hline \multicolumn{1}{|c|}{ ANO } & DISSERTAÇÃO & TESE & REVISTA- ANAIS & TOTAL \\
\hline 1998 & & T3 & & 1 \\
\hline 2003 & D6 & & & 1 \\
\hline 2004 & & & & 1 \\
\hline 2006 & D2 -D14 & & A12 - A1 & 2 \\
\hline 2007 & D10 & & A2 & 3 \\
\hline 2008 & & A8 & 1 \\
\hline 2009 & D1-D3-D9 & T1-T2 & A3-A5-A9-A11 & 4 \\
\hline 2010 & D7 & A13 & 7 \\
\hline 2011 & D4-D5-D11-D12-D13 & & A4-A7- A10-A14 & 5 \\
\hline $2012 *$ & D8 & & \\
\hline$*$ Refere-se à busca de publicações até outubro de 2012. TOTAL 31 & \\
\hline
\end{tabular}

\begin{tabular}{|c|c|c|c|c|}
\hline INSTITUIÇÃO & DISSERTAÇÃO & TESE & REVISTA- ANAIS & TOTAL \\
\hline \multicolumn{5}{|l|}{ Outras regiões } \\
\hline UNB & D10-D11 & & & 2 \\
\hline UFRN & & & A1 & 1 \\
\hline \multicolumn{5}{|l|}{ Região Sudeste } \\
\hline IF Triângulo Mineiro & & & A13 & 1 \\
\hline PUC-RJ & & $\mathrm{T} 2$ & & 1 \\
\hline UENF & & T1 & A2-A7 & 3 \\
\hline UFES & & & A14 & 1 \\
\hline UFF & D9 & & A3 & 2 \\
\hline UFMG & D5-D12 & $\mathrm{T} 3$ & & 3 \\
\hline UFSCAR & D13 & & & 1 \\
\hline Cefet-BA & & & A5 & 1 \\
\hline \multicolumn{5}{|l|}{ Região Sul } \\
\hline CEFET RS & & & A8 & 1 \\
\hline CEFET SC & & & A12 & 1 \\
\hline IF SUL RS & & & A10 & 1 \\
\hline FURB (Blumenau) & D14 & & & 1 \\
\hline PUC-PR & & & A4 & 1 \\
\hline PUC-RS & D1 & & & 1 \\
\hline UFPEL (Pelotas) & & & A9-A11 & 2 \\
\hline UFPR & D8 & & A6 & 2 \\
\hline UFRGS & D2-D3-D4 & & & 3 \\
\hline UFSC & D6-D7 & & & 2 \\
\hline TOTAL 31 & & & & \\
\hline
\end{tabular}




\section{Sobre os Autores}

\section{Gerson Tavares do Carmo}

Professor do Programa de Pós-Graduação em Políticas Sociais (PGPS), do Programa de PósGraduação em Cognição e Linguagem (PGCL) e do Curso de Pedagogia do Centro de Ciências do Homem $(\mathrm{CCH})$ da Universidade do Estado do Norte Fluminense Darcy Ribeiro (UENF). gtavares33@yahoo.com.br O autor é pesquisador no campo da educação de jovens e adultos com foco na permanência escolar, na memória e na escrita, atuando na formação de pedagogos e de novos pesquisadores - mestres e doutores. É líder do Grupo de Pesquisa (CNPq) Escrita: poder e subjetividades. No momento coordena três projetos: Diagnóstico da qualidade de ensino no PROEJA da região norte noroeste fluminense: foco em questões formativas e metodológicas (Edital Observatório da Educação, da CAPES/INEP); Centro de Referência e Memória da Educação Popular e da Educação de Jovens e Adultos na região norte e norte noroeste fluminense (Edital ExtPesq FAPERJ); e Escrita Solidária: sistema de suporte à escrita docente e discente sob a perspectiva da Linguagem e das Ciências Naturais no Curso de Pedagogia da UENF (Edital PIBID/CAPES/ INEP). Autor de artigos em revistas e capítulos de livros nas áreas de pesquisa em que atua.

\section{Cintia Tavares do Carmo}

Professora de Educação Básica, Técnica e Tecnológica do Instituto Federal de Educação, Ciência e Tecnologia do Espírito Santo, Campus Cariacica.

cintiata@gmail.com

A coautora é doutoranda do Programa de Pós-graduação em Sociologia Política da Universidade Estadual do Norte Fluminense Darcy Ribeiro, apresentou o artigo "Cursos de PROEJA em dois Institutos Federais de Educação Tecnológica: a permanência escolar em questão”, no Colóquio da AFIRSE, Lisboa/PT, 2013.

\section{Sobre as Editoras Convidadas}

\section{Sandra Regina Sales}

Professora do Programa de Pós-Graduação em Educação, Contextos Contemporâneos e Demandas Populares (PPGEduc) na linha de pesquisa Educação e Diversidades Étnico-Raciais e do Departamento Educação e Sociedade da Universidade Federal Rural do Rio de janeiro.sandrasales@ufrrj.br Informação biográfica: A autora é pesquisadora nos campos da Educação de Jovens e Adultos, Mídia e Educação e Políticas de Ação Afirmativa no Ensino Superior. Integra o Grupo de Pesquisa (CNPq) Políticas de trans-formação: pesquisas em educaşão e comunicação, do qual é líder, e o Laboratório de Estudos Afrobrasileiros - LEAFRO. Atualmente desenvolve as pesquisas $A$ EJ $A$ e a diversidade na mídia: uma análise das representações dos sujeitos, dos atores e das políticas educacionais nas revistas semanais brasileiras e Que educaşão para que cidadão? Discursos influentes na Educação de Jovens e Adultos no Brasil (1995-2013). É coorganizadora do livro Educação de Jovens e Adultos: políticas e práticas educativas (2011) e tem publicado artigos em revistas e capítulos de livros nas áreas de pesquisa nas quais atua.

\section{Jane Paiva}

Professora do Programa de Pós-Graduação em Educação (ProPEd), na Linha de Pesquisa Educação Inclusiva e Processos Educacionais e do Curso de Pedagogia da Faculdade de Educação da Universidade do Estado do Rio de Janeiro (UERJ). 
janepaiva@terra.com.br

Informação biográfica: A autora é pesquisadora no campo da educação de jovens e adultos, atuando na formação de pedagogos e de novos pesquisadores — mestres e doutores. É líder do Grupo de Pesquisa (CNPq) Aprendizados ao longo da vida: sujeitos, políticas e processos educativos. No momento desenvolve a pesquisa integrada (com a Universidade Estadual de Campinas e a Universidade Federal de Juiz de Fora) Diagnóstico da qualidade de ensino na educação de jovens e adultos: um estudo de caso nos municípios de Campinas, Juiz. de Fora e Rio de Janeiro, financiada pelo Edital Observatório da Educação, da CAPES/INEP; e coordena as ações do projeto de pesquisa e extensão do Centro de Referência e Memória da Educação Popular e da Educação de Jovens e Adultos (CReMEJA). Autora de artigos em revistas e capítulos de livros no campo.

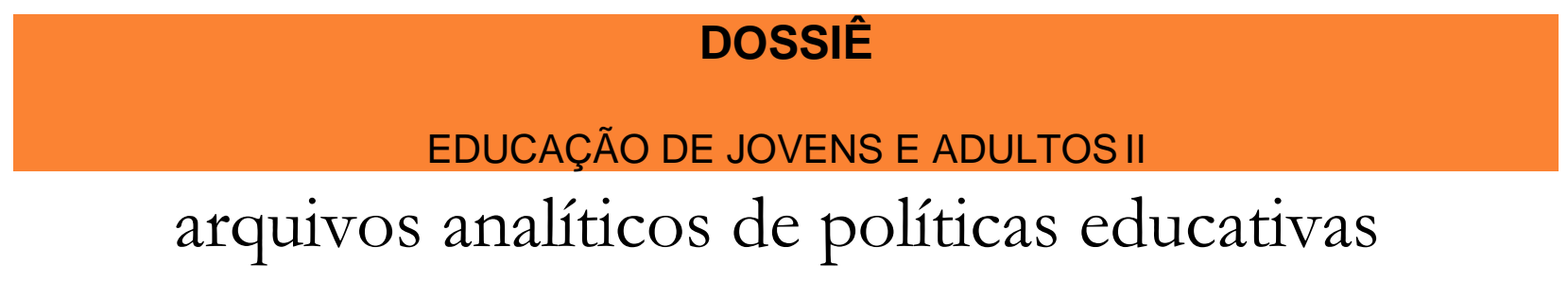

Volumen 22 Número $63 \quad 30$ de junho de 2014 ISSN 1068-2341

(c)

SORERTIGHISRESERVED Copyright e retido pelo/a o autor/a (ou primeiro co-autor) que outorga o direito da primeira publicação à revista Arquivos Analíticos de Políticas Educativas. Más informação da licença de Creative Commons encontram-se em http://creativecommons.org/licenses/by-nc-nd/2.5. Qualquer outro uso deve ser aprovado em conjunto pelo/s autor/es e por AAPE/EPAA. AAPE/EPAA é publicada por Mary Lou Fulton Institute Teachers College da Arizona State University. Os textos publicados em AAPE são indexados por CIRC (Clasificación Integrada de Revistas Científicas, Espanha) DIALNET (Espanha), Directory of Open Access Journals, Education Full Text (H.W. Wilson), EBSCO Education Research Complete, , ERIC, , QUALIS A2 (Brasil), SCImago Journal Rank; SCOPUS, SOCOLAR (China). Contribua com comentários e sugestões a http://epaa.info/wordpress/ ou para Gustavo E. Fischman fischman@asu.edu.

Curta a nossa comunidade EPAA's Facebook https://www.facebook.com/EPAAAAPE e Twitterfeed@epaa_aape. 


\section{arquivos analíticos de políticas educativas conselho editorial}

Editor: Gustavo E. Fischman (Arizona State University) Editores Associados: Rosa Maria Bueno Fisher e Luis A. Gandin (Universidade Federal do Rio Grande do Sul)

Dalila Andrade de Oliveira Universidade Federal de Minas Gerais, Brasil

Paulo Carrano Universidade Federal Fluminense, Brasil Alicia Maria Catalano de Bonamino Pontificia Universidade Católica-Rio, Brasil

Fabiana de Amorim Marcello Universidade Luterana do Brasil, Canoas, Brasil

Alexandre Fernandez Vaz Universidade Federal de Santa Catarina, Brasil

Gaudêncio Frigotto Universidade do Estado do Rio de Alfredo M Gomes Universidade Federal de Pernambuco, Brasil

Petronilha Beatriz Gonçalves e Silva Universidade Federal de São Carlos, Brasil

Nadja Herman Pontificia Universidade Católica -Rio Grande do Sul, Brasil

José Machado Pais Instituto de Ciências Sociais da Universidade de Lisboa, Portugal

Wenceslao Machado de Oliveira Jr. Universidade Estadual de Campinas, Brasil
Jefferson Mainardes Universidade Estadual de Ponta Grossa, Brasil

Luciano Mendes de Faria Filho Universidade Federal de Minas Gerais, Brasil

Lia Raquel Moreira Oliveira Universidade do Minho, Portugal

Belmira Oliveira Bueno Universidade de São Paulo, Brasil

António Teodoro Universidade Lusófona, Portugal Janeiro, Brasil

Pia L. Wong California State University Sacramento, U.S.A

Sandra Regina Sales Universidade Federal Rural do Rio de Janeiro, Brasil

Elba Siqueira Sá Barreto Fundação Carlos Chagas, Brasil

Manuela Terrasêca Universidade do Porto, Portugal

Robert Verhine Universidade Federal da Bahia, Brasil

Antônio A. S. Zuin Universidade Federal de São Carlos, Brasil 


\section{education policy analysis archives editorial board}

Editor Gustavo E. Fischman (Arizona State University)

Associate Editors: Audrey Amrein-Beardsley (Arizona State University), Rick Mintrop, (University of California, Jeanne M. Powers (Arizona State University)

Jessica Allen University of Colorado, Boulder

Gary Anderson New York University

Michael W. Apple University of Wisconsin, Madison

Angela Arzubiaga Arizona State University

David C. Berliner Arizona State University

Bickel Marshall University

Henry Braun Boston College

Eric Camburn University of Wisconsin, Madison

Wendy C. Chi* University of Colorado, Boulder

Casey Cobb University of Connecticut

Arnold Danzig Arizona State University

Antonia Darder University of Illinois, UrbanaChampaign

Linda Darling-Hammond Stanford University

Chad d'Entremont Strategies for Children

John Diamond Harvard University

Tara Donahue Learning Point Associates

Sherman Dorn University of South Florida

Christopher Joseph Frey Bowling Green State University

Melissa Lynn Freeman* Adams State College

Amy Garrett Dikkers University of Minnesota

V Glass Arizona State University

Ronald Glass University of California, Santa Cruz

Harvey Goldstein Bristol University

Jacob P. K. Gross Indiana University

Eric M. Haas WestEd

Kimberly Joy Howard* University of Southern California

Aimee Howley Ohio University

Craig Howley Ohio University

Steve Klees University of Maryland

Jaekyung Lee SUNY Buffalo
Christopher Lubienski University of Illinois, UrbanaChampaign

Sarah Lubienski University of Illinois, UrbanaChampaign

Samuel R. Lucas University of California, Berkeley

Maria Martinez-Coslo University of Texas, Arlington

William Mathis University of Colorado, Boulder Robert

Tristan McCowan Institute of Education, London

Heinrich Mintrop University of California, Berkeley

Michele S. Moses University of Colorado, Boulder

Julianne Moss University of Melbourne

Sharon Nichols University of Texas, San Antonio

Noga O'Connor University of Iowa

João Paraskveva University of Massachusetts, Dartmouth

Laurence Parker University of Illinois, UrbanaChampaign

Susan L. Robertson Bristol University John Rogers University of California, Los Angeles A. G. Rud Purdue University Felicia C. Sanders The Pennsylvania State University Janelle Scott University of California, Berkeley

Kimberly Scott Arizona State University Dorothy Shipps Baruch College/CUNY Gene

Maria Teresa Tatto Michigan State University

Larisa Warhol University of Connecticut

Cally Waite Social Science Research Council

John Weathers University of Colorado, Colorado Springs

Kevin Welner University of Colorado, Boulder Ed Wiley University of Colorado, Boulder

Terrence G. Wiley Arizona State University John Willinsky Stanford University

Kyo Yamashiro University of California, Los Angeles

* Members of the New Scholars Board 


\author{
archivos analíticos de políticas educativas \\ consejo editorial \\ Editor: Gustavo E. Fischman (Arizona State University) \\ Editores. Asociados Alejandro Canales (UNAM) y Jesús Romero Morante (Universidad de Cantabria)
}

Armando Alcántara Santuario Instituto de Investigaciones sobre la Universidad y la Educación, UNAM México

Claudio Almonacid Universidad Metropolitana de Ciencias de la Educación, Chile

Pilar Arnaiz Sánchez Universidad de Murcia, España

Xavier Besalú Costa Universitat de Girona, España

Jose Joaquin Brunner Universidad Diego Portales, Chile

Damián Canales Sánchez Instituto Nacional para la Evaluación de la Educación, México

María Caridad García Universidad Católica del Norte, Chile

Raimundo Cuesta Fernández IES Fray Luis de León, España

Marco Antonio Delgado Fuentes Universidad Iberoamericana, México

Inés Dussel FLACSO, Argentina
Fanni Muñoz Pontificia Universidad Católica de Perú

Imanol Ordorika Instituto de Investigaciones Economicas - UNAM, México

Maria Cristina Parra Sandoval Universidad de Zulia, Venezuela

Miguel A. Pereyra Universidad de Granada, España

Monica Pini Universidad Nacional de San Martín, Argentina

Paula Razquin UNESCO, Francia

Ignacio Rivas Flores Universidad de Málaga, España

Daniel Schugurensky Arizona State University Orlando

Pulido Chaves Universidad Pedagógica

Nacional, Colombia

José Gregorio Rodríguez Universidad Nacional de Colombia

Rafael Feito Alonso Universidad Complutense de Madrid, España

Pedro Flores Crespo Universidad Iberoamericana, México

Verónica García Martínez Universidad Juárez Autónoma de Tabasco, México

Francisco F. García Pérez Universidad de Sevilla, España

Edna Luna Serrano Universidad Autónoma de Baja California, México

Alma Maldonado Departamento de Investigaciones Educativas, Centro de Investigación y de Estudios Avanzados, México

Alejandro Márquez Jiménez Instituto de Investigaciones sobre la Universidad y la Educación, UNAM México

José Felipe Martínez Fernández University of California Los Angeles, USA

Miriam Rodríguez Vargas Universidad Autónoma de Tamaulipas, México

Mario Rueda Beltrán Instituto de Investigaciones sobre la Universidad y la Educación, UNAM México

José Luis San Fabián Maroto Universidad de Oviedo, España

Yengny Marisol Silva Laya Universidad Iberoamericana, México

Aida Terrón Bañuelos Universidad de Oviedo, España

Jurjo Torres Santomé Universidad de la Coruña, España

Antoni Verger Planells University of Amsterdam, Holanda

Mario Yapu Universidad Para la Investigación Estratégica, Bolivia 